

\section{Surficial Geology \\ Of}

Mount Rainier National Park

Washington 


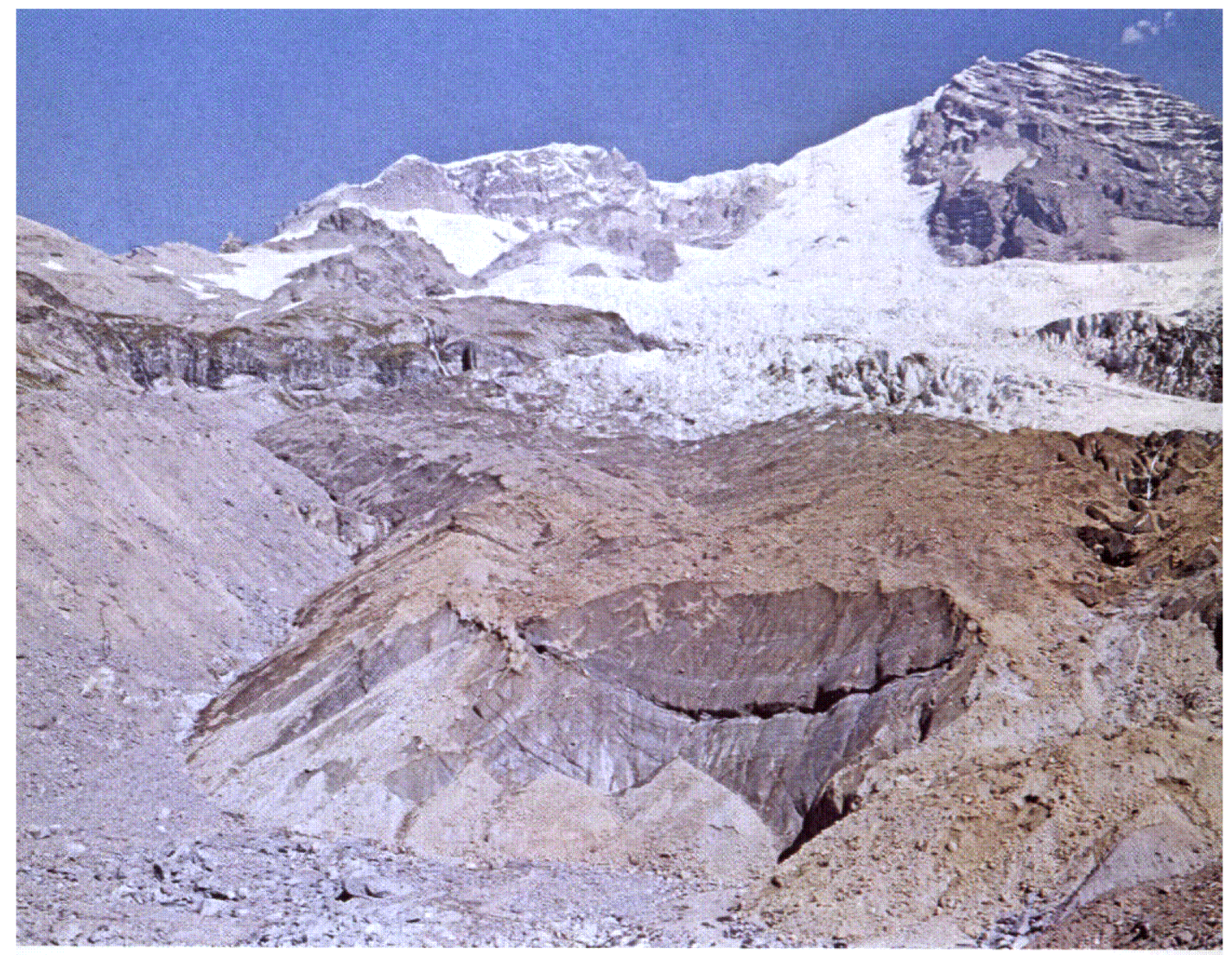

AVALANCHE DEPOSIT of yellowish-orange clay and rock debris lies on top of Tahoma Glacier on the west side of Mount Rainier. The avalanche originated in rockfalls at the cliffs at the upper left and slid down to the end of the glacier. The cliffs form the headwall of Sunset Amphitheater; Point Success is the peak at the right. The front of the glacier, in the foreground, is about 200 feet high. 
Surficial Geology of

Mount Rainier National Park Washington

By

Dwight R. Crandell

GEOLOGICAL SURVEY BULLETIN I288 
FrontisPiEce. Avalanche deposit of clay and debris on Tahoma Glacier.

Plate 1. Surficial geology of Mount Rainier

National Park, Washington....... In pocket

Figure 1. East side of Mount Rainier........... 4

2. Distribution of pumice deposits in Mount

Rainier National Park............ 6

3. Recent pumice deposits on the floor of a cirque near Sluiskin Falls.......... 8

4. Map of Mount Rainier National Park..... 12

5. Old drift on the north side of Glacier Basin. 14

6. Bouldery till exposed in a gully on the north side of Glacier Basin.......... 15

7. Hayden Creek till along the Mowich Lake road................... 16

8. Yellowish-orange rinds on stones of gray volcanic rocks . . . . . . . . . . . 17

9. Extent of glaciers at Mount Rainier and in the adjacent mountains during the most recent major glaciation........ 19

10. Rock-glacier deposit at The Palisades..... 21

11. Protalus rampart on the north side of Sunrise Ridge ............... 22

12. Pumice layer $O$ underlies a yellowish-orange mudflow at Ricksecker Point. . . . . . . . 24

13. Osceola Mudflow exposed on the south bank of Inter Fork.............. 26

14. Pumice layer $C$ veneers a Burroughs Mountain moraine .............. 29

15. End moraine of Garda Drift formed by Emmons Glacier................. 31

16. Breadcrust bomb............... 32

17. Mudflow from Mount Rainier on top of pumice layer Y from Mount St. Helens. . 34

18. Alluvial cone at the east base of Mount Wow ......................... 37

19. Avalanche deposit of rock debris from Little Tahoma Peak............. 39

TABLE 1. Characteristics, sources, and ages of pumice layers in Mount Rainier National Park. . . 10 


\title{
Surficial geology of Mount Rainier National Park Washington
}

\author{
By Dwight R. Crandell
}

\section{Surficial Deposits Record Recent Geological Events}

Much of the ground surface around Mount Rainier volcano is directly underlain by loose geologic deposits that veneer the hard rock formations. Examples of these deposits are sand and gravel bars along the rivers, ridges of loose rock debris beside the glaciers, and sloping aprons of rock fragments beneath almost every cliff. Even though they are generally thin and inconspicuous when compared with the rock formations, these surficial deposits are clues to geologic events that have profoundly influenced the shape of the park's landscape. Thus, from the character and extent of glacial deposits one can judge the age and size of former glaciers that carved the cirques and deep canyons of the park; from the mudflows which streamed down nearly every valley one can infer the age and size of huge landslides of the past that helped determine Mount Rainier's present shape; and from the pumice deposits some of the volcano's recent eruptive activity can be reconstructed. 
The map (plate 1, in pocket) that accompanies this description of the surficial deposits of Mount Rainier National Park shows the location of the various geologic formations, and the explanation shows the formations arranged in order of their relative age, with the oldest at the bottom. The text describes the surficial deposits in sequence from older to younger. A discussion of the pumice deposits of the park, which were not mapped, is followed by a description of the formations shown on the geologic map.

Inspection of the geologic map may lead the viewer to question why the surficial deposits are shown in more detail in a zone several miles wide around the base of the volcano than elsewhere. This is partly because the zone is largely near or above timberline, relatively accessible, and the surficial deposits there can be readily recognized, differentiated, and mapped. In contrast, access is more difficult in the heavily timbered parts of the park, and surficial deposits there are generally blanketed by a dense virgin forest and are rarely exposed. Geologic investigations in such areas of the park were of a reconnaissance nature.

\section{How Surficial Deposits Are Formed}

Most of the surficial deposits were formed by geologic processes that occurred over and over again, and some of these processes are still going on today. One kind of geologic process is the erosion of rock by glaciers, the transportation of the resulting debris downvalley by the ice, and the eventual deposition of the debris at and beyond the glacier margins. The resulting surficial deposits are referred to collectively as glacial drift. They include rock debris deposited by glacier ice as well as sand and gravel formed by melt water from glaciers. The term till refers to an unsorted mixture of rock debris formed directly by a glacier. Moraines are ridges of till that have been deposited along the sides of a glacier (lateral moraines) or at its front (end moraines).

A second geologic process responsible for many surficial deposits in the park is landsliding. Some large slides of the past became mixed with water as they moved downslope into valleys and formed mudflows. Mudflows are mixtures of water and rock debris of many sizes and during movement resemble wet concrete. Falls of masses of rock from cliffs are also a type of landslide; they range in size 
from small pieces that accumulate at the base of the cliff and form a sloping talus of angular rock fragments to falls of whole sections of a cliff. Rockfalls that become broken into material of many sizes sometimes move rapidly far downvalley as avalanches of rock debris.

A geologic process that is going on today just as it did in the past is the erosion, transportation, and deposition of rock debris by streams and rivers. The sand and gravel deposits in river bars and terraces that result from this process are called alluvium.

Still another geologic process that has resulted in some widespread but thin surficial deposits is volcanism. Within the last 10,000 years or so, Mount Rainier has repeatedly erupted clouds of pumice that have settled to the ground over much of the eastern part of the park. Pumice is a type of lava that is so full of gas bubbles that it is light enough to float on water. Because of its light weight, pumice can be transported great distances by wind.

Some geologic processes other than those mentioned are responsible for a few of the surficial deposits in the park; these will be discussed as the specific deposits are described.

\section{Landslides, Mudflows, and Mount Rainier's Shape}

Landslides have played an unusually important role at Mount Rainier, both in determining the volcano's shape and in forming some of the park's surficial deposits. Although landslides are common features elsewhere, those at Mount Rainier are exceptionally large. The largest one destroyed much of the volcano's former summit about 5,700 years ago. The top of Mount Rainier today is the crest of a small lava cone that perhaps is only about 2,000 years old. The cone occupies a broad depression whose broken rim is represented by Gibraltar Rock, Point Success, and the ridge between Liberty Cap and Russell Cliff (fig. 1). The broad depression resulted from great landslides of rock from the former summit of the volcano, which had become decomposed to clay and weakened by hot volcanic gases and solutions over many centuries. These slides of wet clayey rock formed a truly spectacular mudflow that streamed downvalley from the volcano at least 70 miles. 


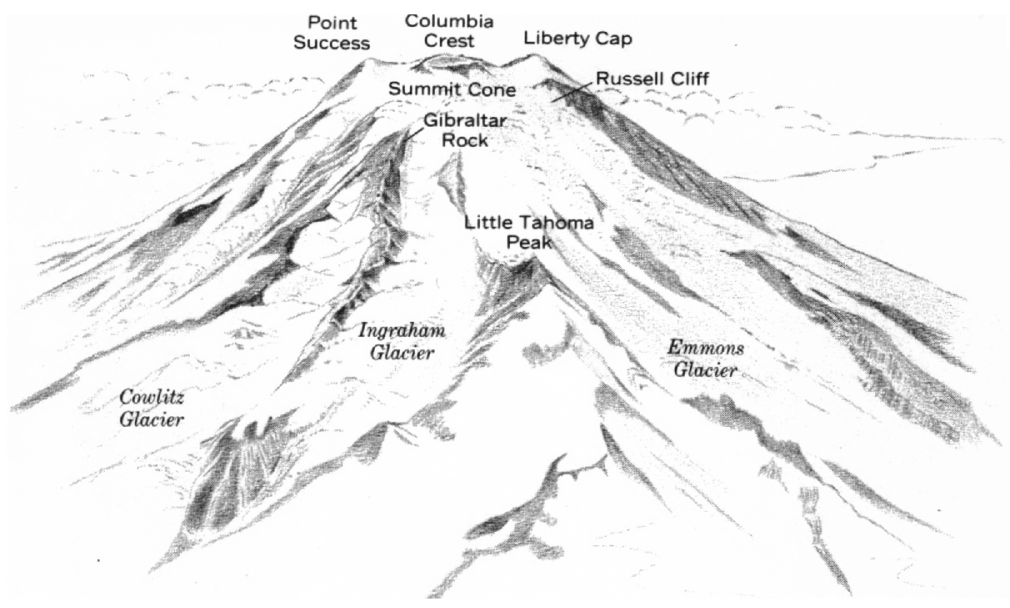

EAST SIDE OF MOUNT RAINIER. The summit cone lies within a broad depression whose rim is represented by Point Success, Gibraltar Rock, and the ridge between Liberty Cap and Russell Cliff. The depression was formed when the former top of the volcano, which consisted of rock that had been partly altered to clay, slid off to the east and descended Emmons Glacier in a tremendous avalanche that produced the Osceola Mudflow 5,700 years ago. The distance from Point Success to Liberty Cap is $11 \frac{1}{4}$ miles, and the summit crater is about 1,300 feet across. (Fig. 1)

Similar but smaller slides of clayey rock have occurred repeatedly on other parts of the volcano during the last 10,000 years and have also resulted in clayey mudflows. These mudflows contain clays that originated from longcontinued steaming and chemical breakdown of volcanic rocks. Decomposed and altered rocks of this kind at Sunset Amphitheater on the west side of Mount Rainier are part of a central plug of lava that cooled and solidified in a former throat of the volcano. Although its shape is similar to that of depressions carved wholly by glacial erosion, Sunset Amphitheater was probably formed in large part by repeated landslides and is analogous in origin to the former broad depression at the summit of the volcano. Several clayey mudflows in the valleys on the west side of the volcano originated in these slides at Sunset Amphitheater, and the landslide of yellowish-orange clay and altered rock from the same source that lies at the end of Tahoma Glacier (frontispiece) is no more than a few decades old. 


\section{Recent Pumice Deposits}

Thin layers of pumice erupted by Mount Rainier and by other volcanoes in the Cascade Range are the most widespread surficial deposits in the park. Although these deposits are not represented on the geologic map because of their thinness, the distribution of five layers erupted by Mount Rainier is shown in figure 2.

The ages of most of the pumice deposits are known within a few hundred years because wood buried with them can be dated by determining the proportion of radioactive carbon the wood contains. Other surficial deposits that are interbedded with pumice layers of known age can be dated approximately. Elsewhere, the age of a surficial deposit, such as a moraine, can be limited by the presence or absence of a certain pumice layer on top of it (see sketches at the bottom of the map explanation [plate 1]) - if the pumice is present, the deposit must be older; if the pumice layer is not on top, the deposit is younger than the pumice. This method of dating surficial deposits, of course, can be used only in areas covered by the pumice layer in question.

The most distinctive and widespread pumice deposits at Mount Rainier-and those most useful for purposes of dating other surficial deposits-were erupted by two other volcanoes and brought to the park by southwesterly winds. Layer $O$ (table 1) is about 2 inches thick and blankets the entire park and adjoining region. It can be readily recognized by a distinctive yellowish-orange color (fig. 3) and a flourlike texture. When it is studied under the microscope, its characteristics are found to correspond precisely to those of thè pumice that was erupted by Mount Mazama volcano at the site of Crater Lake, Oreg., about 6,600 years ago. The extreme fineness of layer $O$ can be attributed to the distance of 250 miles that separates Mount Rainier from Crater Lake. 


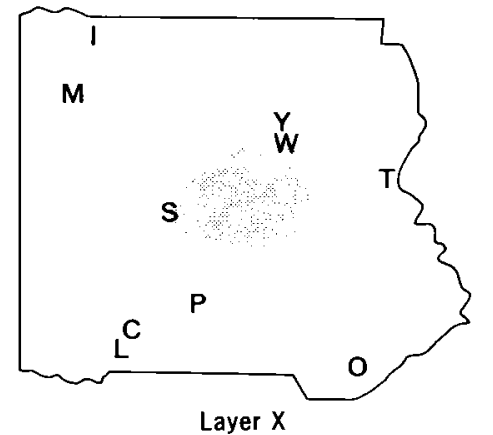

(Between 110 and 150 years old)

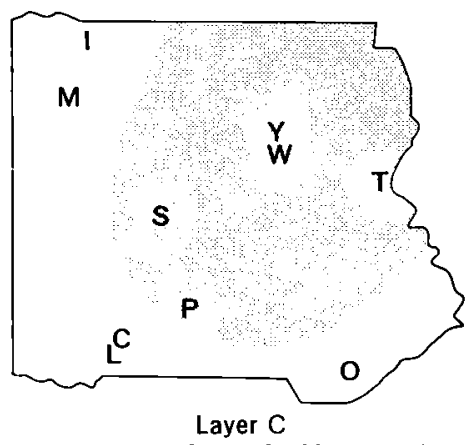

(Between 2,150 and 2,500 years old)

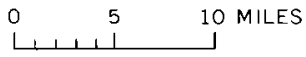

DISTRIBUTION OF PUMICE DEPOSITS in Mount Rainier National Park. Only the pumice layers erupted by Mount Rainier within the last 10,000 years are shown. The extent of layer $X$ is based on the recognition of the pumice at certain localities, regardless of its thickness; other layers are shown wherever they are at least 1 inch thick. Letters represent the following localities: C, Cougar Rock campground; I, Ipsut Creek campground; L, Longmire; M, Mowich Lake; O, Ohanapecosh campground; P, Paradise Park; S, summit crater; T, Tipsoo Lake; W, White River campground; and $Y$, Yakima Park. Based on studies by $D$. R. Mullineaux. (Fig. 2) 


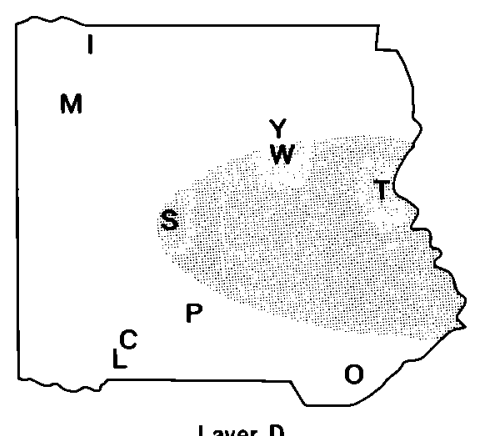

Layer D

(Between 5,800 and 6,600 years old)

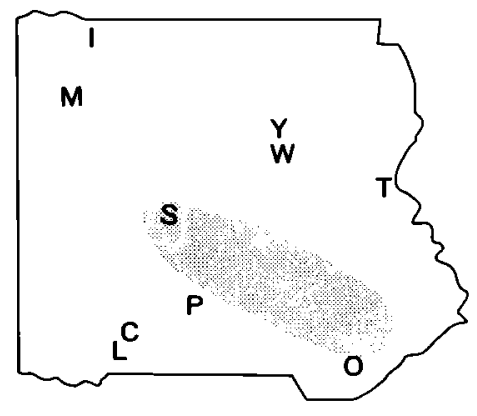

Layer $L$

(Between 5,800 and 6,600 years old)

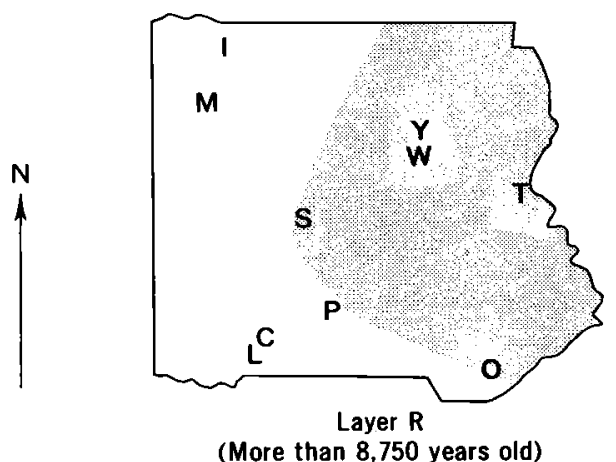




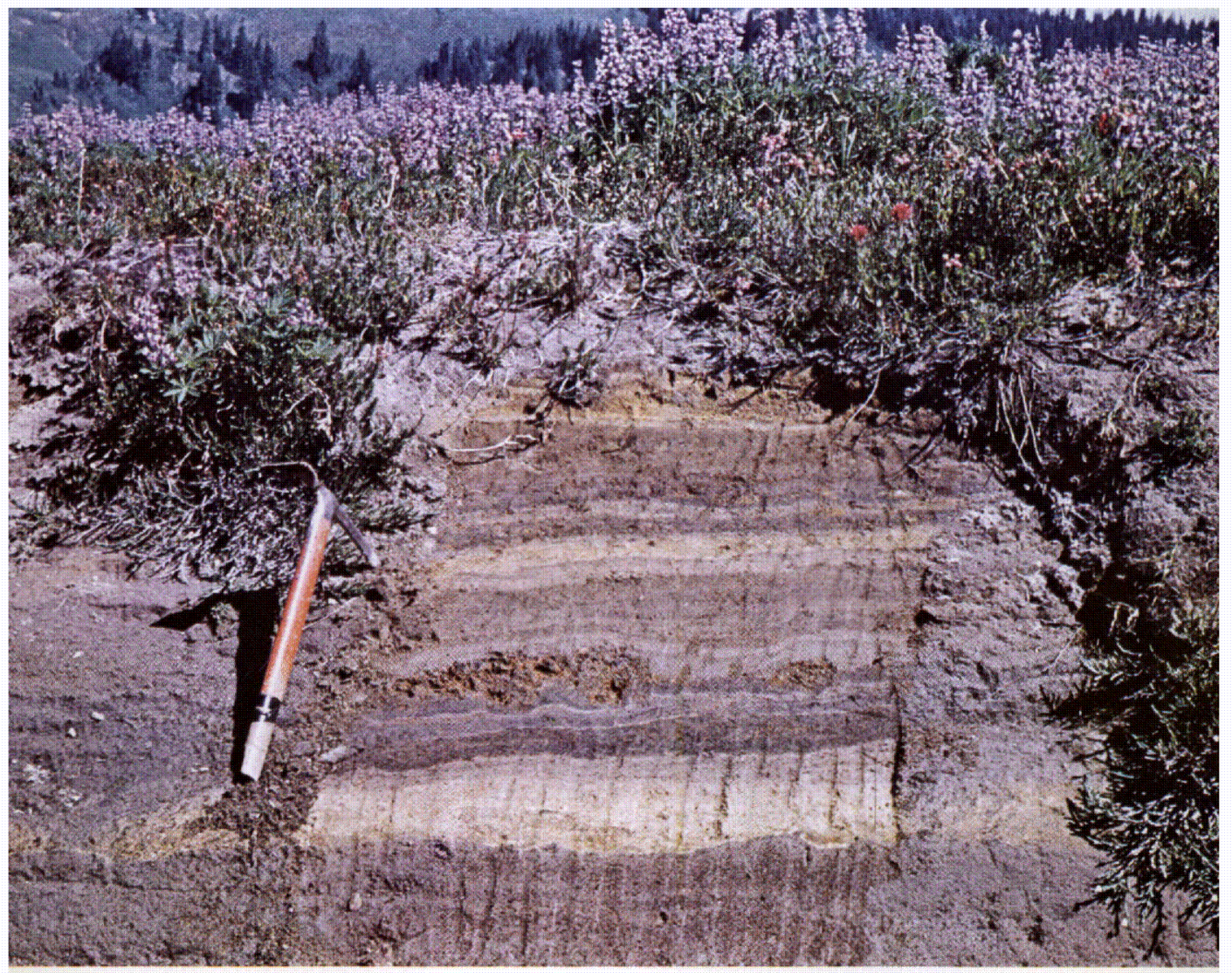

RECENT PUMICE DEPOSITS on the floor of a cirque a quarter of a mile southeast of Sluiskin Falls. The yellow bed at the bottom is layer 0 , which was erupted at the site of Crater Lake, Ore., about 6,600 years ago. The yellowish-brown pumice a few inches above layer 0 is layer $D$, which was erupted by Mount Rainier more than 5,800 years ago, and the light-yellowish-brown pumice bed at the top of the outcrop is layer $Y$, which originated at Mount St. Helens volcano between 3,300 and 4,000 years ago. (Fig. 3 ) 
Pumice layers $\mathrm{Y}$ and $\mathrm{W}$ originated at Mount St. Helens volcano, which is about 50 miles southwest of Mount Rainier. Both layers cover lobate areas that extend far northeastward from their source. The centerline of the lobe of layer $Y$ lies near the west edge of the park, where the pumice is commonly as much as 18 inches thick. The thickness of layer $Y$ decreases to the east, and the layer is thin or absent in the southeast corner of the park. Layer $\mathrm{Y}$ is light yellowish brown (fig. 3), which helps to distinguish it from layer $\mathrm{W}$, which is white. The center of the lobe of layer $\mathrm{W}$ lies near the east boundary of the park, where the pumice is about 2 inches thick.

The thickest and most widespread pumice from Mount Rainier is layer $\mathrm{C}$, which is found throughout the eastern and northeastern parts of the park. Layer $\mathrm{X}$, which represents Mount Rainier's most recent known eruption, was formed about the middle of the last century. It is found only in a small area close to the volcano.

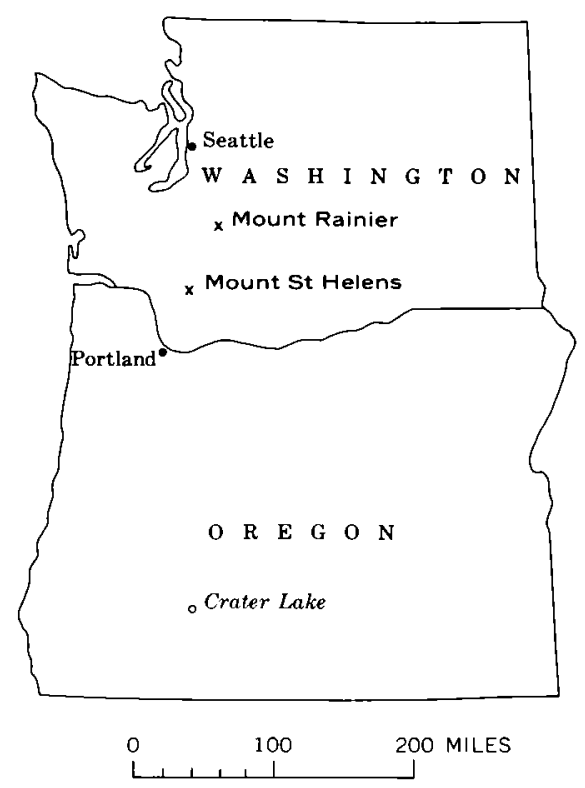


TABLE 1.-Characteristics, sources, and ages of pumice layer's in Mount Rainier National Park

[Based on studies by D. R. Mullineaux]

\begin{tabular}{|c|c|c|c|c|c|c|}
\hline \multirow[b]{2}{*}{$\begin{array}{l}\text { Pumice } \\
\text { layer }\end{array}$} & \multicolumn{2}{|c|}{$\begin{array}{l}\text { Common range } \\
\text { of thickness } \\
\text { in park (inches) }\end{array}$} & \multirow{2}{*}{$\begin{array}{c}\text { Range in } \\
\text { diameter } \\
\text { of pumice } \\
\text { fragments } \\
\text { (inches) }\end{array}$} & \multirow[b]{2}{*}{ Color } & \multirow[b]{2}{*}{ Source } & \multirow{2}{*}{$\begin{array}{l}\text { Approximate } \\
\text { age in } 1968 \text {, } \\
\text { or limiting } \\
\text { dates } \\
\text { (years ago) }\end{array}$} \\
\hline & $\begin{array}{l}\text { West } \\
\text { side }\end{array}$ & $\begin{array}{l}\text { East } \\
\text { side }\end{array}$ & & & & \\
\hline $\mathrm{X}$. & .Absent & 1 & $1 / 4-2$ & $\begin{array}{l}\text { Light } \\
\text { olive } \\
\text { gray. }\end{array}$ & $\begin{array}{l}\text { Mount } \\
\text { Rainier. }\end{array}$ & $100-150$ \\
\hline $\mathbf{W} \ldots \ldots$ & .. $0-1$ & $1-3$ & $\begin{array}{l}\text { Medium } \\
\text { sand. }\end{array}$ & White......... & $\begin{array}{r}\text { Mount St. } \\
\text { Helens. }\end{array}$ & 2450 \\
\hline $\mathrm{C}$ & Absent & $1-8$ & $1 / 4-8$ & Brown & $\begin{array}{l}\text { Mount } \\
\text { Rainier. }\end{array}$ & $2,150-2,500$ \\
\hline $\mathrm{Y} \ldots$ & $5-20$ & $1-5$ & $\begin{array}{c}\text { Coarse } \\
\text { sand. }\end{array}$ & Yellow........ & $\begin{array}{r}\text { Mount St. } \\
\text { Helens. }\end{array}$ & $3,300-4,000$ \\
\hline D............ & Absent & $0-6$ & $1 / 4-6$ & Brown & $\begin{array}{l}\text { Mount } \\
\text { Rainier. }\end{array}$ & $5,800-6,600$ \\
\hline $\mathrm{L} \ldots \ldots \ldots$ & Absent & $0-8$ & $1 / 4-2$ & Brown & $\begin{array}{l}\text { Mount } \\
\text { Rainier. }\end{array}$ & $5,800-6,600$ \\
\hline $0 \ldots$ & $1-3$ & $1-3$ & $\begin{array}{l}\text { Silt and } \\
\text { very } \\
\text { fine } \\
\text { sand. }\end{array}$ & $\begin{array}{r}\text { Yellowish } \\
\text { orange. }\end{array}$ & $\begin{array}{l}\text { Mount } \\
\text { Mazama. }\end{array}$ & About 6,600 \\
\hline $\mathrm{R}$. & Absent & $0-5$ & $1 / 8-1$ & $\begin{array}{c}\text { Reddish } \\
\text { brown. }\end{array}$ & $\begin{array}{l}\text { Mount } \\
\text { Rainier. }\end{array}$ & $8,750-11,000 ?$ \\
\hline
\end{tabular}

1The $X$ pumice occurs as scattered fragments and does not form a continuous layer.

${ }^{2}$ Ages of more than 150 and less than 6,000 years cited in this report are based on radiocarbon determinations which have been corrected by the use of a $C_{14}$ half life of 5,730 years and for variations in atmospheric $\mathrm{C}_{14}(\mathrm{H}$. E. Suess, written communication to Meyer Rubin, 1968). 


\section{Surficial Deposits Shown on the Geologic Map}

\section{OLD DRIFT}

The age and extent of the glaciers responsible for the old drift are not known, but glaciers evidently covered this part of the Cascade Range very early in the development of Mount Rainier, perhaps even before the volcano first appeared. The old drift consists mostly of glacial deposits overlying bedrock formations that are older than Mount Rainier and underlying lava flows from the volcano. The lava flows are of a rock known as andesite, ${ }^{1}$ and they form many of the ridges that radiate from the base of the volcano, such as Mazama and Rampart Ridges and Burroughs Mountain. Each old drift deposit shown on the geologic map contains compact till, but some also include mudflows and rubbles of volcanic origin.

Old drift exposed in a roadcut upslope from Narada Falls lies on a surface of glacially smoothed and scratched bedrock (fig. 4, locality 1). The till at this locality is overlain by a pumice-bearing deposit of sand and fine gravel that is interbedded with mudflows. This deposit, together with the till, is about 100 feet thick and is overlain by a lava flow from Mount Rainier that forms Mazama Ridge.

Old drift at the west end of Burroughs Mountain (fig. 4, locality 2) consists of about 800 feet of compact bouldery gray till and beds of sand and fine gravel. It is overlain, consecutively, by a deposit of loose gray and red volcanic rubble about 300 feet thick and by a lava flow from Mount Rainier. In Glacier Basin (fig. 4, locality 3) old till lies on top of compact mudflows and hard bedrock (fig. 5). The till is very compact and bouldery (fig. 6) and is several hundred feet thick. Banked against it is an old lava flow from Mount Rainier, and both the till and the flow are overlain, in turn, by a red volcanic rubble and a younger lava flow from Mount Rainier. The red rubble probably is part of the deposit that overlies the old drift at the west end of Burroughs Mountain. The old mudflows, the till, and the red rubble have been intruded by a wall-like andesite dike that forms a prominent ridge along the north side of Glacier Basin.

\footnotetext{
${ }^{1}$ Rock formations in Mount Rainier National Park are described in some of the reports listed at the end of the text.
} 


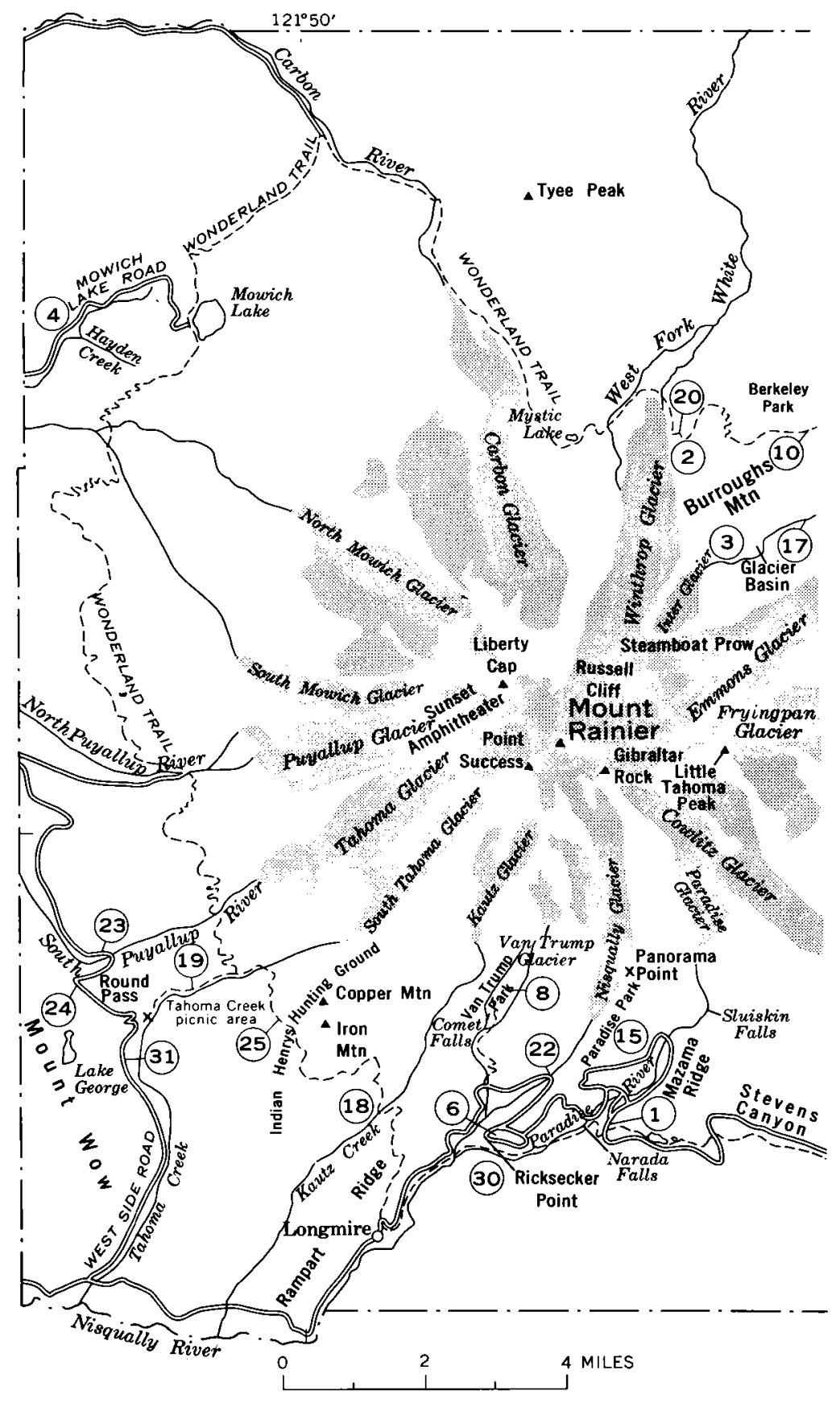

MAP OF MOUNT RAINIER NATIONAL PARK, showing 




localities mentioned in text (numbered). (Fig. 4) 


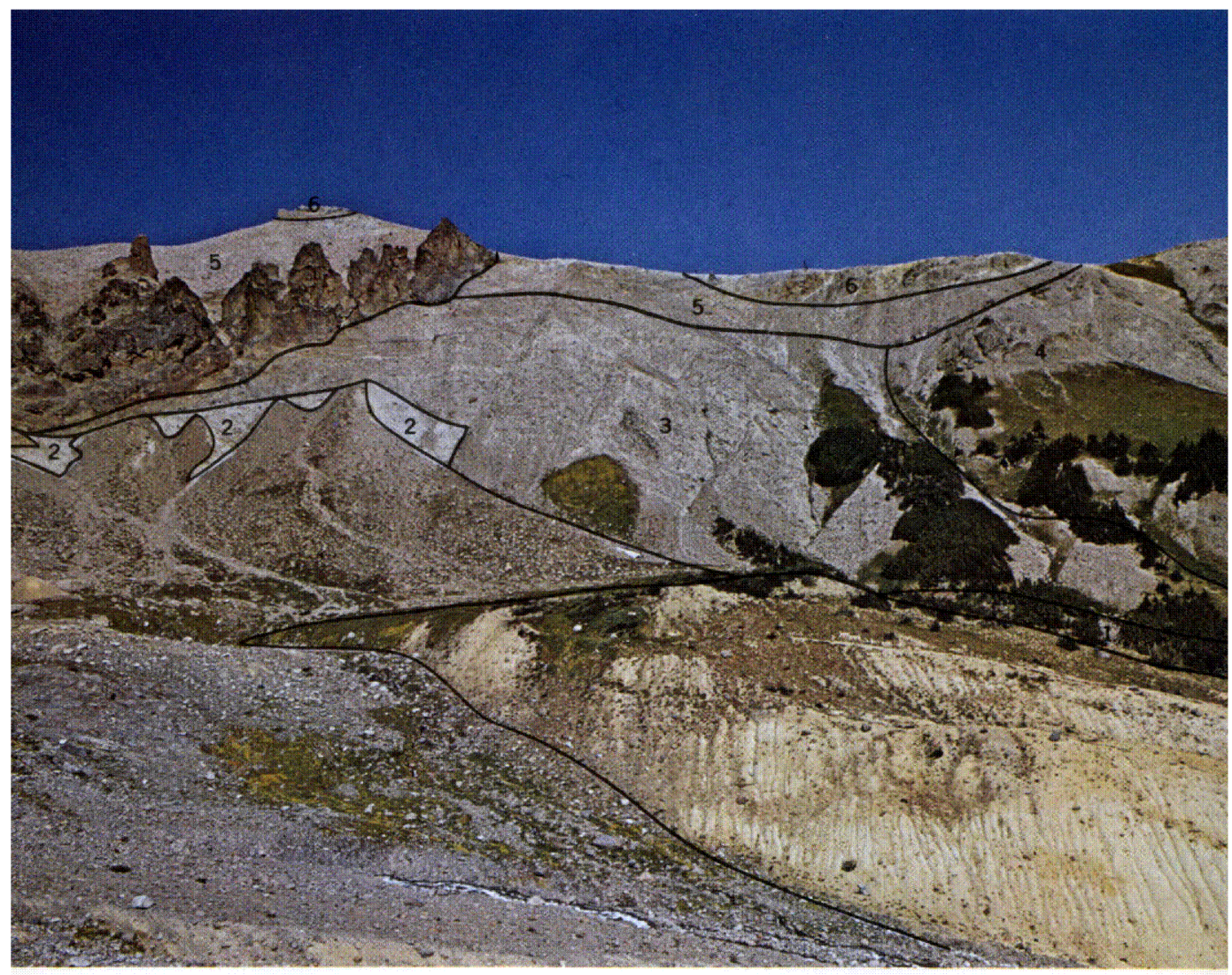

OLD DRIFT on the north side of Glacier Basin. The geologic formations, in order of decreasing geologic age, are: 1, Bedrock much older than Mount Rainier; 2, mudflows which came from an old Mount Rainier volcano; 3 , old drift, which consists mostly of very bouldery till; 4 , an old andesite lava flow from Mount Rainier; 5, a red volcanic rubble from Mount Rainier; 6, a younger andesite lava flow from Mount Rainier; and 7 , an andesite dike. The age relation of the dike to the younger lava flow is not known. The yellow deposit in the right foreground is a Garda moraine of Inter Glacier; it is about 200 feet high and consists almost wholly of Osceola Mudflow, which was eroded from the floor of the basin and redeposited by the glacier. The deposits in the left foreground and middle distance are alluvium younger than the moraine. (Fig. 5) 


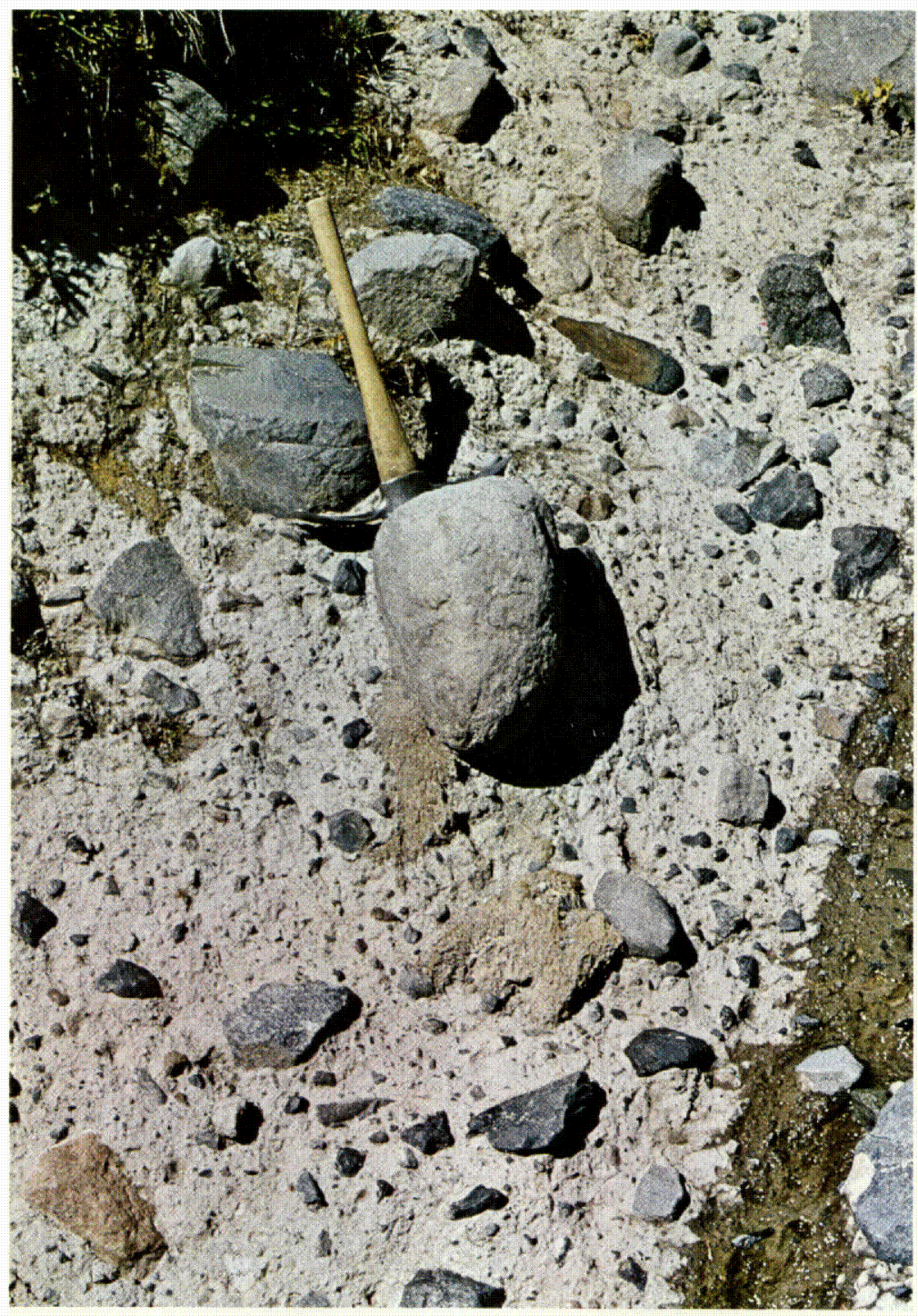

BOULDERY TILL exposed in a gully on the north side of Glacier Basin is part of the old drift. The boulders and smaller stones of various colors in the till are derived from the bedrock that underlies the volcano. The stones are contained in a very hard and compact matrix of brownish-gray silt and sand. (Fig. 6) 


\section{HAYDEN CREEK DRIFT}

The Hayden Creek Drift is here named for a stony till that is intermittently exposed in cuts along the Mowich Lake Road (fig. 7) from a point near the mouth of Hayden Creek (fig. 4, locality 4) westward beyond the park boundary.

The distribution of Hayden Creek Drift outside the park, as well as the drift's presence on some high ridges within the park, indicates deposition during a glaciation of icecap

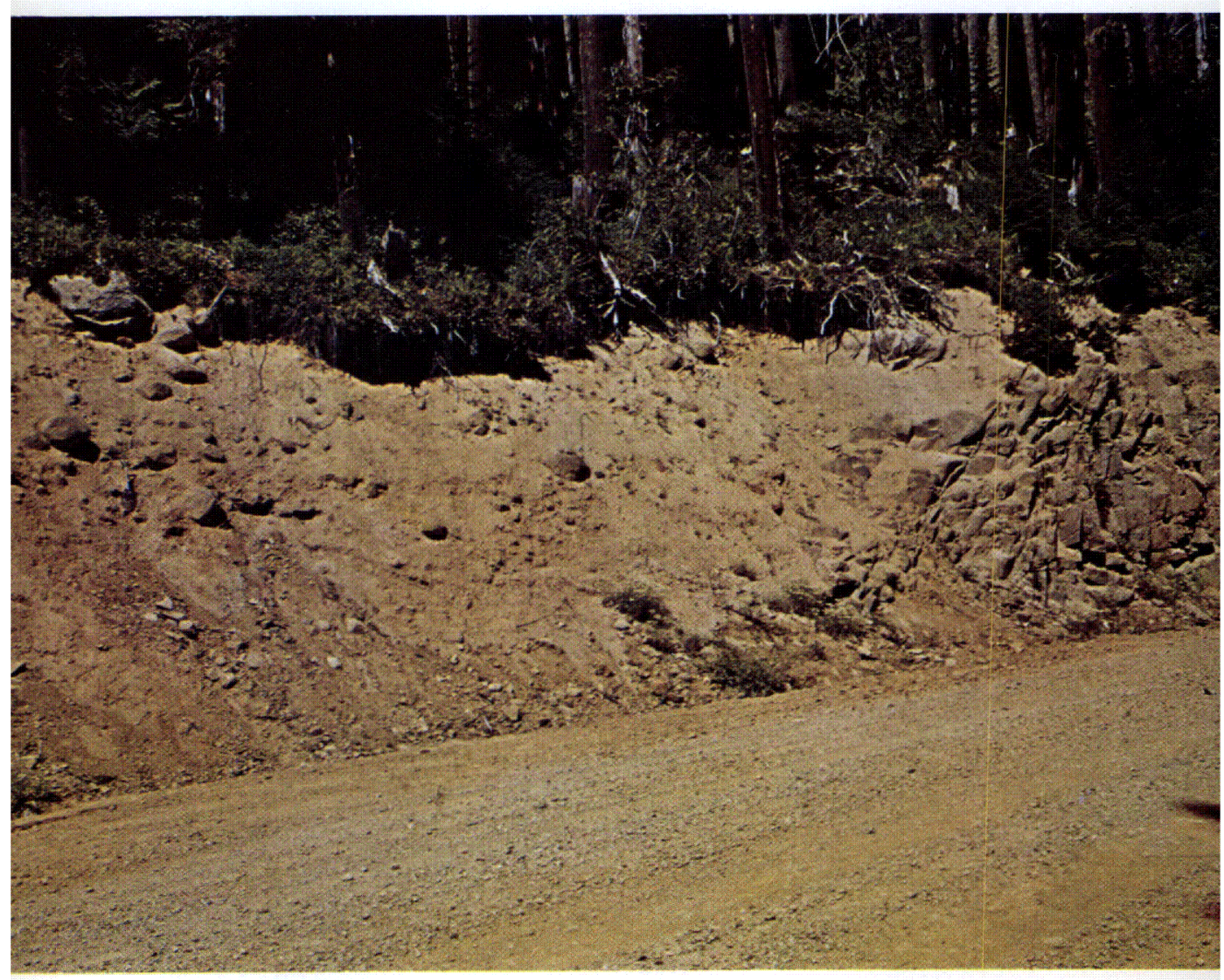

HAYDEN CREEK TILL along the Mowich Lake Road. The thick brown oxidized zone at the top of the till is typical of the Hayden Creek Drift. Bedrock at the right is much older than Mount Rainier volcano. (Fig. 7) 
proportions, when glaciers west of Mount Rainier locally reached the western front of the Cascade Range. The entire park was covered by ice at that time. The Hayden Creek Drift probably was formed during a glacial episode that occurred between 35,000 and 50,000 years ago.

Extensive weathering in the Hayden Creek Drift shows it to be older than the Evans Creek Drift (described next), which was formed during the most recent major glaciation. Although initially brownish gray, the Hayden Creek till has been weathered to dark yellowish brown to a depth of 6-8 feet below the ground surface. Stones in the upper few feet of the till have been partly decomposed; these stones have weathered rinds or shells $1-3 \mathrm{~mm}$ thick (fig. 8). Hayden Creek Drift was found at the summits of Iron and Copper Mountains and at the top of a ridge that extends eastward from Tyee Peak. A brown bouldery till at least 100 feet thick on a ridge northwest of The Palisades probably is also Hayden Creek Drift.

Hayden Creek Drift underlies a thick deposit of Mount Rainier pumice on the north valley wall of the White River about 2 miles southeast of Yakima Park (fig. 4, locality 5).

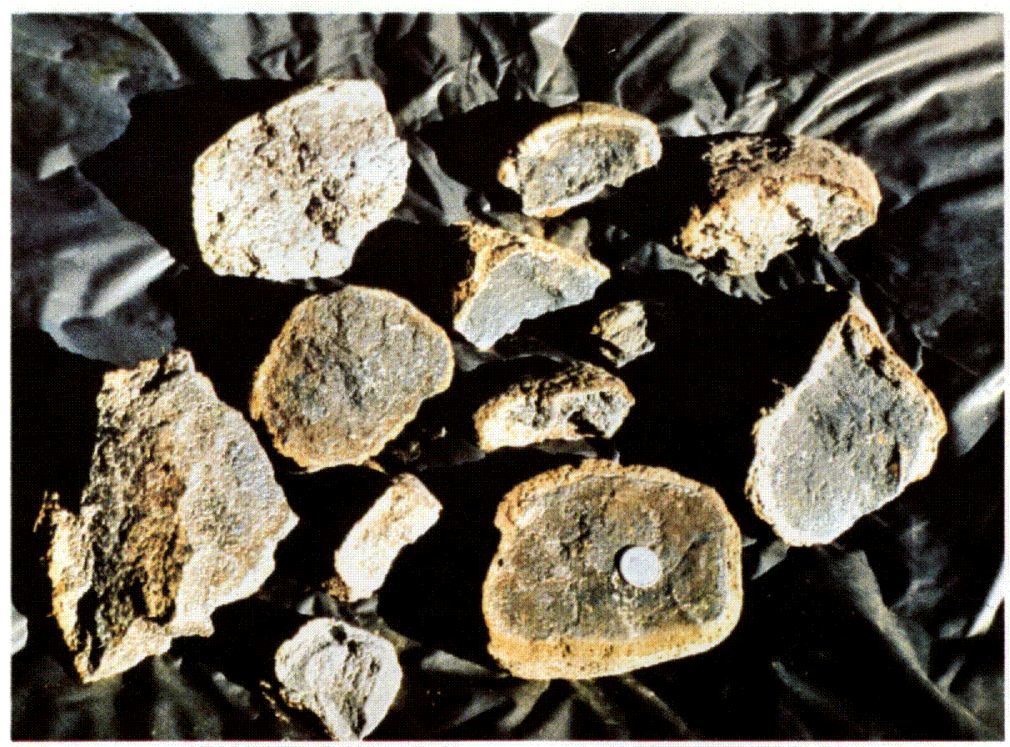

YELLOWISH-ORANGE RINDS on these stones of dark-gray volcanic rocks are the result of weathering over a long period of time. Weathered rinds like these, but about half as thick, are present on stones near the surface of the Hayden Creek Drift. (Fig. 8) 
The pumice can be seen in a roadcut a short distance west of Yakima Creek where it is overlain by an old talus deposit and Evans Creek till. Wood in the pumice is more than 38,000 years old, as determined by radiocarbon dating. More than 50 feet of Hayden Creek till is exposed beneath the pumice in a steep bank downslope from the highway.

\section{EVANS CREEK DRIFT}

Between about 25,000 and 15,000 years ago Mount Rainier and the adjacent mountains were again buried by large glaciers ; these glaciers formed the Evans Creek Drift, which consists of till as well as stream-deposited sand and gravel. These glaciers developed during an early part of the last major glaciation of the Pleistocene (Ice Age) ; at that time lateral moraines were deposited along the margins of glaciers high on the sides of some valleys and even along the crests of some divides, as at Ricksecker Point (fig. 4, locality 6) and Rampart Ridge. Till in the moraines is generally very coarse, loose or slightly compacted, and as much as 50 feet thick. The till is mostly gray or purplish gray, but it has a yellowish-brown oxidized zone in the upper 2 or 3 feet that has been formed by weathering processes since the till was deposited. Stones in this oxidized zone rarely have weathered rinds. Evans Creek till is especially well exposed in roadcuts along the north side of the White River valley east of Yakima Park (fig. 4, locality 7).

At the time the Evans Creek Drift was cieposited, icefields and glaciers mantled the slopes of the volcano above an altitude of about 5,000 feet. Each major valley was occupied by a glacier 1,000-1,500 feet thick which extended from 5-35 miles beyond the park boundaries (fig. 9).

\section{MUDFLOW AT VAN TRUMP PARK}

Between 11,000 and 15,000 years ago a large landslide of rock from the summit of Mount Rainier swept down the south flank of the volcano and spread as a mudflow over Van Trump Park. There it deposited a yellowish-orange unsorted mixture of clay, sand, and rock debris which is as much as 6 feet thick on the ridgetop at Van Trump Park (fig. 4, locality 8 ) and is 20 feet thick in the valley of Van 
Trump Creek northeast of Comet Falls. The mudflow is widespread in areas beyond an end moraine of Van Trump Glacier that probably was formed about 11,000 years ago, but it does not overlie the moraine itself and thus is older.

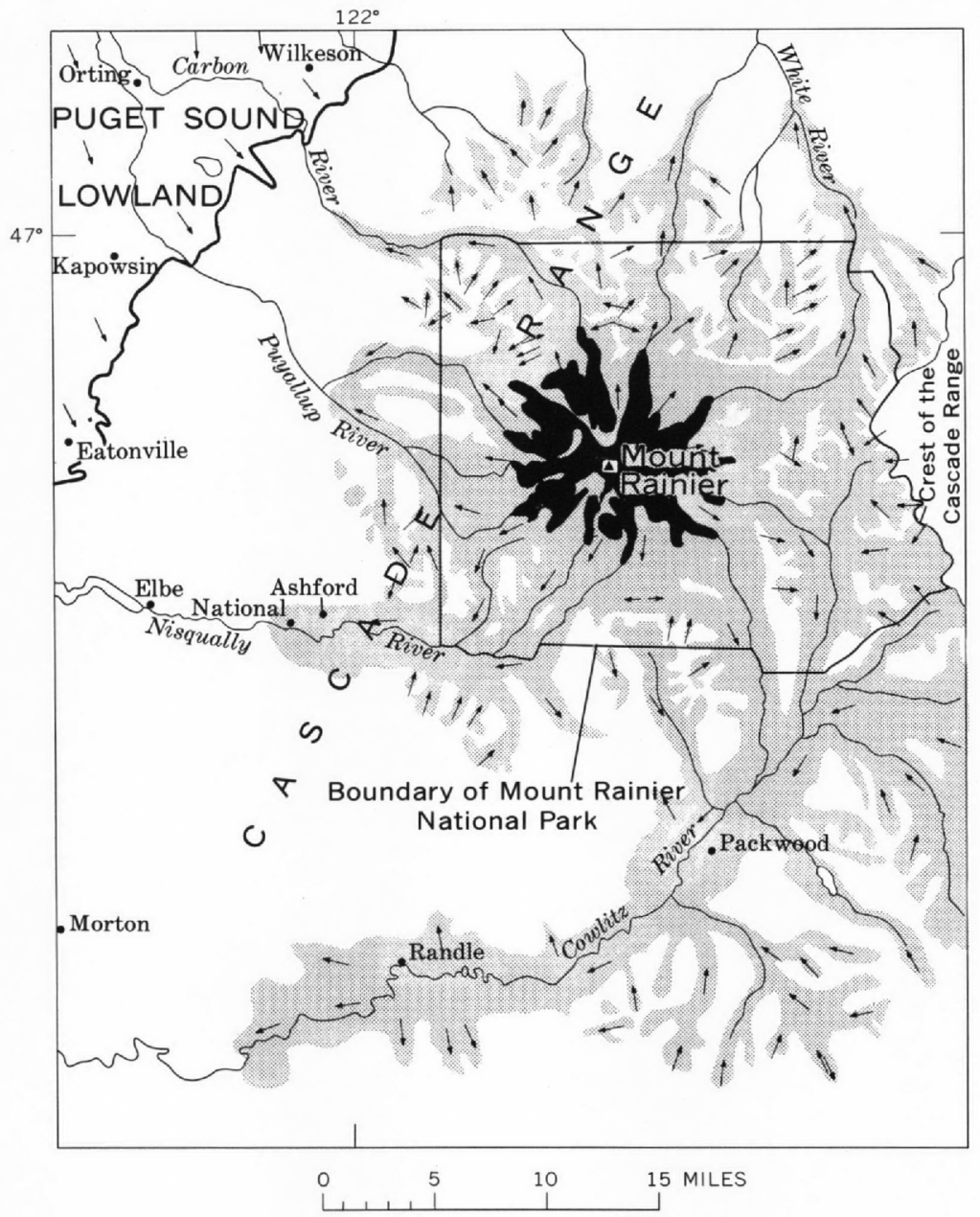

EXTENT OF GLACIERS at Mount Rainier and in the adjacent mountains during the most recent major glaciation is shown by stipple pattern. The heavy black line at the upper left marks the boundary between the Puget Sound lowland and the Cascade Range. This line also represents the southeast edge of a massive glacier in the lowland which originated in southwestern Canada and reached this part of the lowland about 14,000 years ago. The arrows show the direction of glacier movement. Black areas are covered by glaciers today. (Fig. 9) 


\section{McNEELEY DRIFT}

McNeeley Drift, named in this report, consists of till in moraines formed during the latest part of the most recent major glaciation, probably about 11,000 years ago. The name of the drift is taken from McNeeley Peak, which is north of Yakima Park. A typical moraine lies within a north-facing cirque half a mile south of the peak (fig. 4, locality 9). Weathering extends to a depth of 15 inches or less in the till, and stones in the till that have been decomposed by weathering processes are rare. McNeeley moraines are found adjacent to some large active valley glaciers on Mount Rainier and in some cirques at altitudes between 5,500 and 6,700 feet. Areas in front of cirque moraines generally consist of either glacier-scoured bedrock or featureless Evans Creek Drift. McNeeley moraines are sharp crested and little modified by erosion. They range from single low narrow ridges of till to accumulations as much as 1,000 feet wide that are distinguished by multiple ridges. One of the largest McNeeley moraines dams Mystic Lake on the north side of the park, and the Wonderland Trail crosses another at the south end of Berkeley Park (fig. 4, locality 10). A small McNeeley cirque moraine can be seen along the highway between Tipsoo Lake and Chinook Pass (fig. 4, locality 11).

\section{ROCK-GLACIER DEPOSITS}

Rock-glacier deposits are thick flat-lying or gently sloping accumulations of coarse angular rock debris that have a lobate form and a surface marked by pits and by ridges and furrows. Angular blocks several tens of feet in maximum dimension are generally strewn over the surface. A depression separates the upslope margin of most rock-glacier deposits from nearby talus (fig. 10). The fronts of rockglacier deposits are abrupt, steep, and from 25 to 100 feet high. Rock-glacier deposits owe their shape and size to flowage of accumulations of rock debris that contain ice. 
Active rock glaciers differ from true glaciers chiefly in having a very high proportion of rock debris to ice. All of those in the park were formed during a late part of the most recent major glaciation and are inactive now.

Most rock-glacier deposits occupy north- or east-facing cirques within an altitude range of 5,500 to 6,600 feet. Many are closely associated with McNeeley Drift, and in some cirques they merge with McNeeley moraines. All are about the same age as the McNeeley Drift.

A trail just east of Mount Fremont crosses a representative rock-glacier deposit (fig. 4, locality 12), and one of the largest in the park occupies an east-facing cirque between the Palisades and Hidden Lake (fig. 10; fig. 4, locality 13).

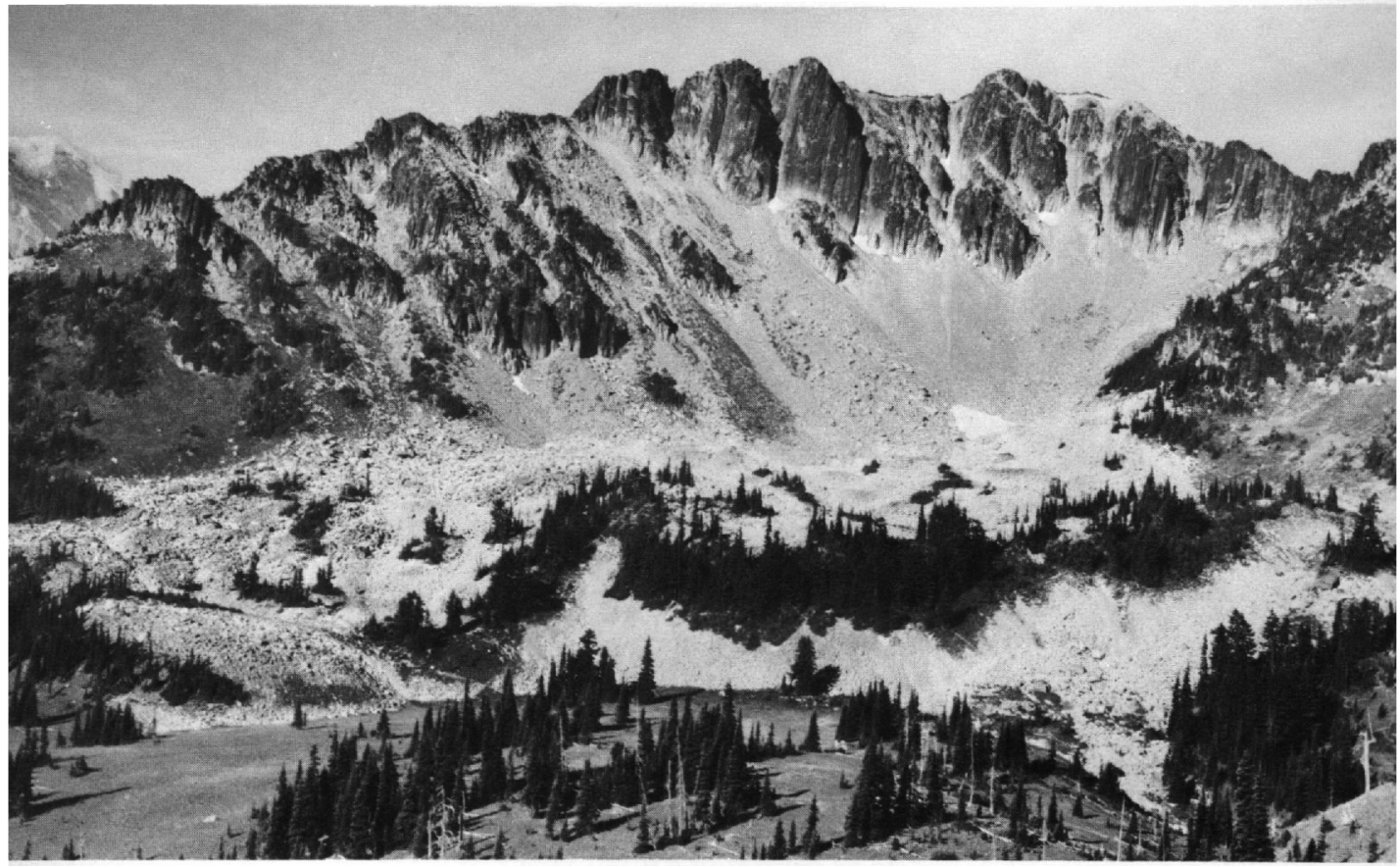

ROCK-GLACIER DEPOSIT in the foreground is an accumulation of lightcolored rock debris derived from the cliffs of The Palisades in the northeastern section of the park. The deposit covers an area of about 100 acres and is $100-300$ feet thick. The steeply sloping deposit of rock debris just below the cliffs is a talus. (Fig. 10) 


\section{PROTALUS RAMPARTS}

Protalus ramparts are ridges of loose angular rock fragments that lie a few tens of feet beyond the toes of taluses (fig. 11). Blocks larger than 3 feet in diameter are rare, and most ramparts seem to consist chiefly of fragments 6 inches to 2 feet in diameter. The ridges are generally 10-30 feet

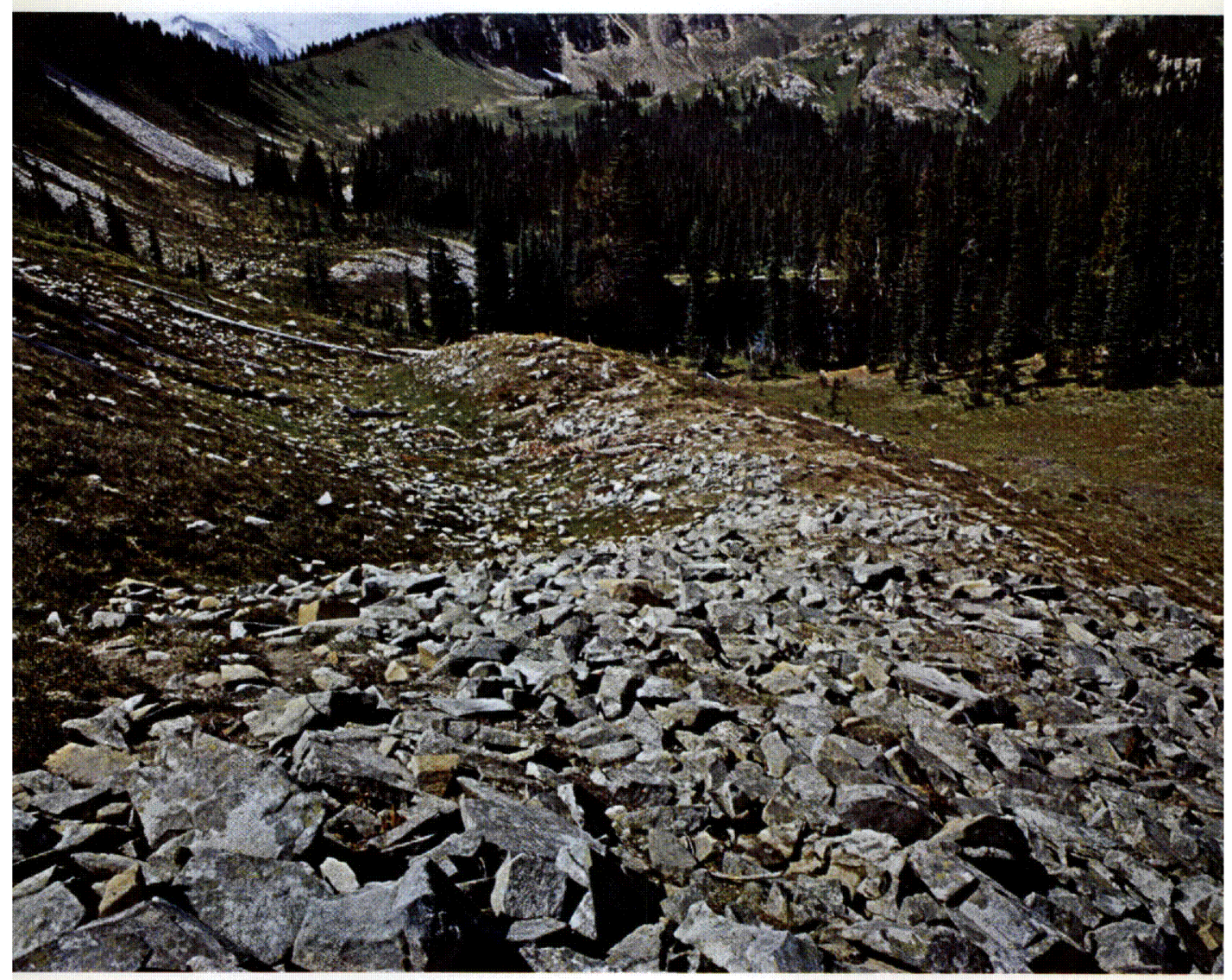

PROTALUS RAMPART on the north side of Sunrise Ridge is separated from the partly vegetated talus on the left by a depression 5-6 feet deep and 20-30 feet wide. A thick wedge-shaped snowbank blanketed the talus and the depression when the arcuate rampart was formed. (Fig. 11) 
wide and 5-15 feet high on the side next to the talus. In ground plan they range from straight to sinuous; many are arcuate and are convex in a direction away from the talus. Their distribution, shape, and nearness to taluses indicate that they were formed at some time when thick persistent snowbanks buried the toes of some cliffs and parts of taluses. Rock debris falling from a cliff and sliding down the snowbank accumulated at the toe of the snowbank as a ridge or rampart; a subsequent change in climatic conditions prevented such a large snowbank from forming, so that the falling rock debris then became part of the main talus and building of the rampart ceased.

Most protalus ramparts are the same age as the McNeeley Drift. The close association of protalus ramparts with McNeeley moraines in some cirques suggests that the glacier responsible for the moraine dwindled until only a perennial snowbank remained, at the toe of which the rampart was formed.

The trail to White River Park crosses a typical and readily accessible protalus rampart at the base of Sunrise Ridge (fig. 4, locality 14), and there are several other ramparts associated with McNeeley moraines along the north side of Sunrise Ridge a little to the west.

\section{MUDFLOW AT PARADISE PARK}

A very large landslide of clayey altered rock avalanched down the south side of Mount Rainier between 5,800 and 6,600 years ago. Upon reaching the lower slopes of the volcano, the avalanche became a mudflow that spread over the Paradise area. Here the mudflow deposited a plastic yellowish-orange mixture of unsorted clay, sand, and rock fragments a few inches to more than 15 feet thick. Blocks in the deposit are as large as 6 feet in diameter. The presence of thin remnants on top of Mazama Ridge indicates that the mudflow must have been 600 feet deep in the adjacent 
Paradise River valley. Farther downvalley, at Ricksecker Point, the mudflow was temporarily at least 800 feet deep. The mudflow lies on top of pumice layer $\mathrm{O}$ (fig. 12).

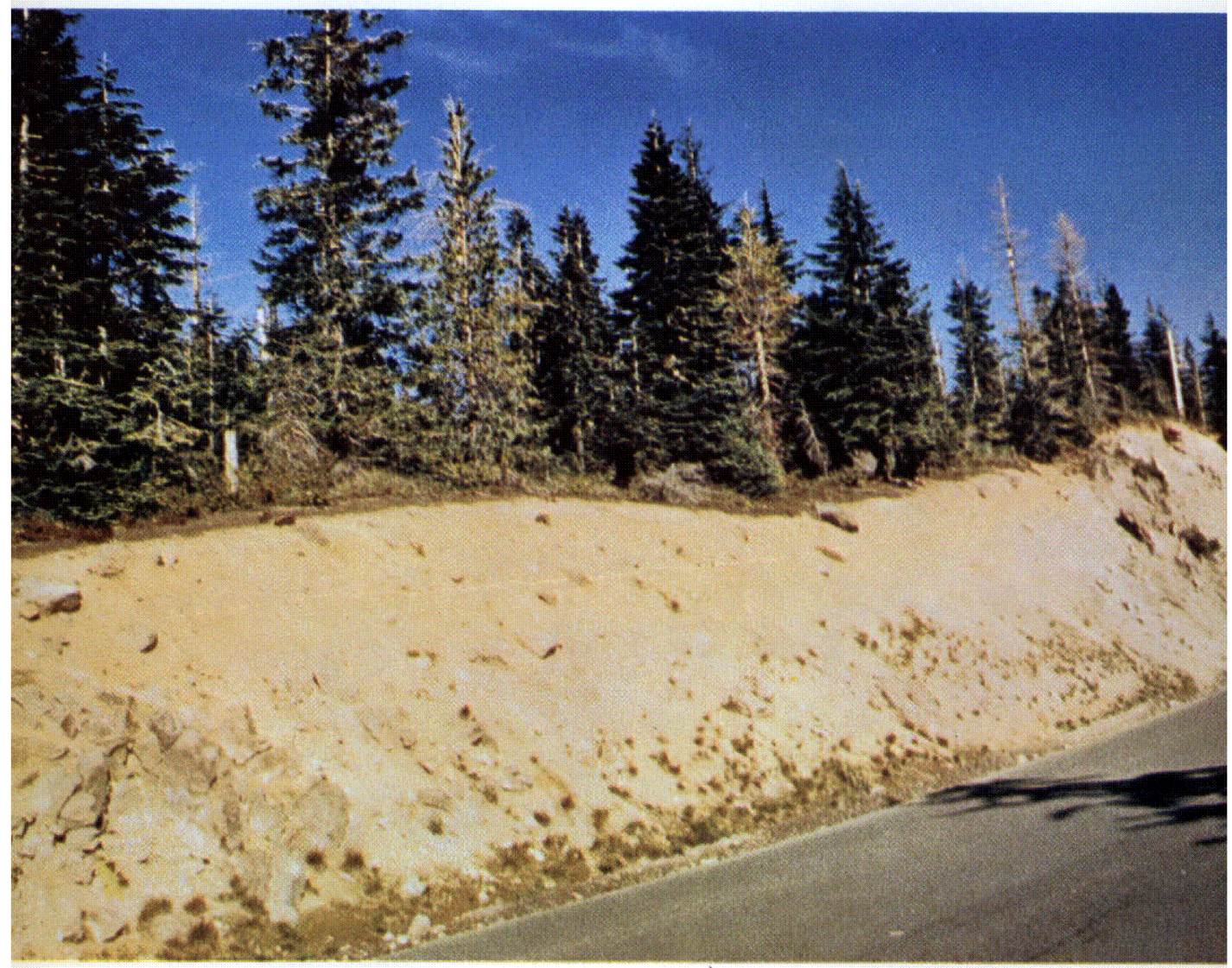

PUMICE LAYER O from Mount Mazama (Crater Lake) forms a thin yellow band at the base of the yellowish-orange mudflow that blankets Paradise Park. This outcrop is at Ricksecker Point, and its height above the floor of the adjacent Paradise River valley indicates that the mudflow was temporarily at least 800 feet deep here. (Fig. 12) 


\section{OSCEOLA MUDFLOW}

The Osceola Mudflow is the largest mudflow that has originated at Mount Rainier and is one of the largest volcanic mudflows in the world. It originally covered an area of more than 100 square miles in the Cascade Range and the Puget Sound lowland, and its volume probably was more than half a cubic mile. Radiocarbon determinations of logs in the mudflow indicate an age of about 5,700 years.

The mudflow is an unsorted mixture of plastic clay, sand, and rock debris that includes boulders as large as 15 feet in diameter (fig. 13). It is purplish gray where fresh and weathers to yellowish orange. Remnants of the mudflow high on the sides of the White River and West Fork valleys show that both valleys were temporarily filled with streams of mud more than 500 feet deep. After the crest of the mudflow passed a given point, most of the material drained away downvalley, leaving veneers a few feet to a few tens of feet thick on the valley walls. Much of the flowing mud finally came to rest in the Puget Sound lowland, 40-70 miles away.

The presence of the Osceola Mudflow on ridgetops above Glacier Basin and at the top of Steamboat Prow indicates that it originated even higher on the volcano. This distribution and a large clay content suggest that the mudflow was caused by huge slides of altered rock material from a former summit of the volcano. These slides probably were triggered by volcanic explosions, and they produced the large craterlike depression at the top of the volcano that contains the present summit lava cone.

Roadcuts expose the mudflow at the White River Ranger Station (fig. 4, locality 16), and one of the best outcrops is in the valley of Inter Fork about 1.5 miles west of White River campground (fig. 13; fig. 4, locality 17). 


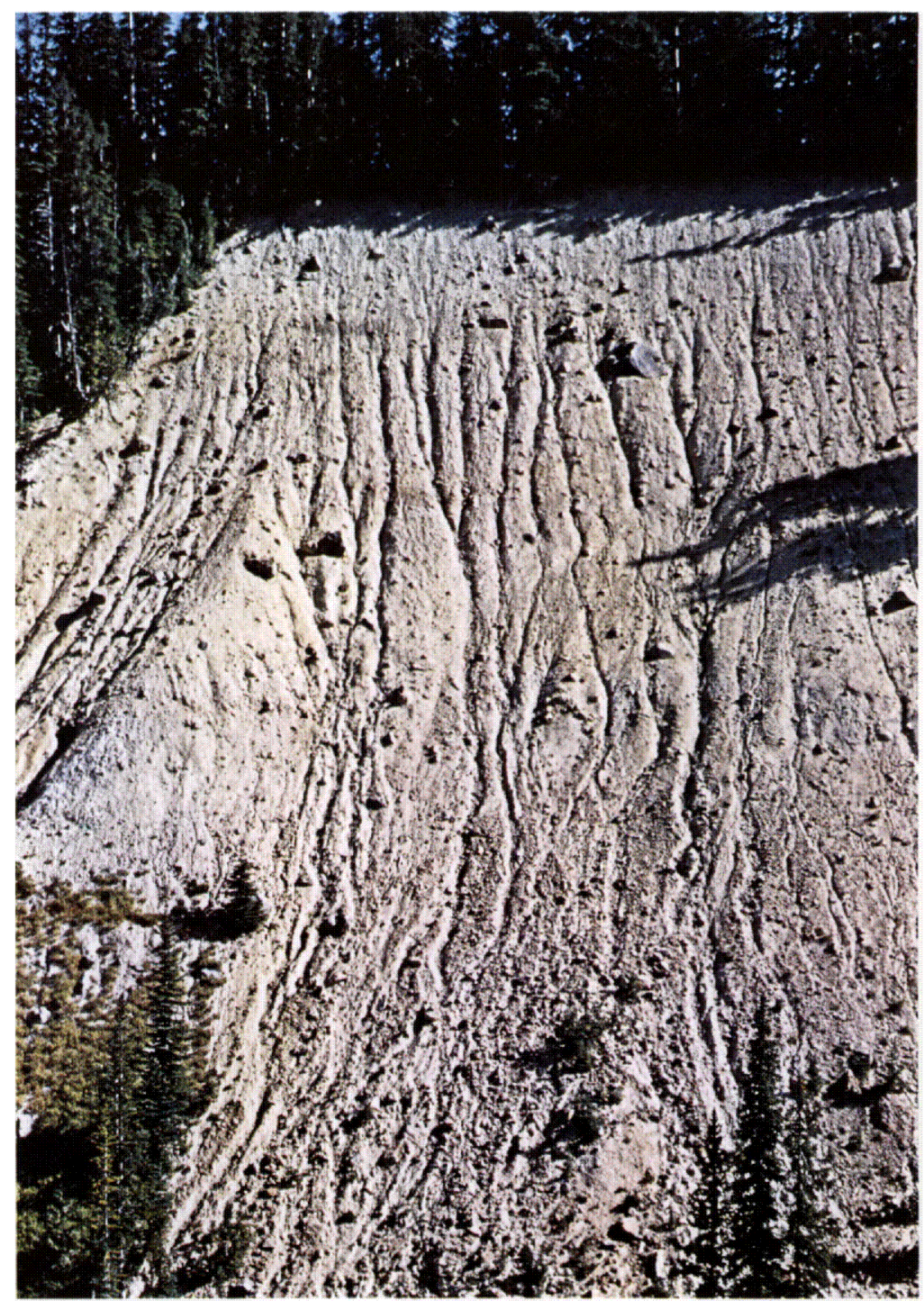

OSCEOLA MUDFLOW is exposed on the south bank of Inter Fork. Slope wash from the bouldery yellow mudflow has nearly hidden the underlying gray Evans Creek till, which can be seen at the lower left. (Fig. 13) 


\section{INTERBEDDED MUDFLOWS AND ALLUVIUM}

Mudflows are interbedded with alluvium in terraces or benches along the sides of nearly every major valley in the park. Individual mudflows are from about 1 to 15 feet thick and typically are unsorted mixtures of sand, clay, and stones of many sizes. Individual mudflows lack bedding, although a succession of several mudflows, or an alternation of mudflows and alluvium, may give an outcrop a layered appearance. Most mudflows are purplish gray where unweathered, and yellowish orange or yellowish brown where weathered. Many of these mudflows resulted from floods caused by eruptions. The volcano has repeatedly erupted hot rock debris and lava flows which melted snow and ice. The resulting floods that cascaded down the flanks of the cone became mudflows by scouring loose alluvium and moraines on the valley floors. Other mudflows, however, probably originated during periods of unusually heavy rainfall, when parts of recent moraines became saturated and slid and flowed downvalley.

Alluvium that is interlayered with the mudflows was formed mainly by streams and rivers like those of today. It generally consists of sand and gravel in which some boulders are as large as 6 feet in maximum diameter, and it ranges in thickness from a few inches to at least 50 feet. Alluvium can be distinguished from mudflows mainly by the presence of bedding and by lenses and layers of wellsorted material.

Pumice layers that locally lie between deposits of alluvium and mudflows are commonly interbedded with rooted stumps, logs, and other organic matter formed on forest floors that have since been buried. As many as four successive buried forest layers can be seen in the steep banks of Kautz Creek near the Wonderland Trail (fig. 4, locality 18), and the north bank of Tahoma Creek shows a similar sequence about a mile upstream from Tahoma Creek campground (fig. 4, locality 19). Some pumice layers, whose age is known, permit age bracketing of interbedded deposits, 
and the presence or absence of other layers on top of the deposits permits subdivision of the mudflows and alluvium into map units of four ages. (See explanation for the geologic map.) Unit $A$ includes deposits older than pumice layer $O$; unit $\mathrm{B}$ contains the deposits younger than layer $\mathrm{O}$ and older than layer $\mathrm{Y}$; unit $\mathrm{C}$ represents the deposits younger than layer $\mathrm{Y}$ but older than layer $\mathrm{W}$; and unit $\mathrm{D}$ includes the deposits younger than layer $\mathrm{W}$. The surface deposit represented on the map commonly is underlain by mudflows and alluvium of older units.

\section{BURROUGHS MOUNTAIN DRIFT}

The Burroughs Mountain Drift was formed during a period of glacier expansion that occurred between about 2,500 and 3,000 years ago. Although the glaciers of the park became only a little larger than they are today, this was a significant change, for during the time since the end of the last major glaciation they had been smaller. Burroughs Mountain moraines can be recognized by the fact that they are older than pumice layer C (fig. 14), and younger than layer $\mathrm{Y}$.

Till in the Burroughs Mountain moraines is gray, generally loose, and not appreciably weathered. The moraines below timberline are densely forested with trees several generations younger than the first forest that became established on the moraines after their formation. Most of the Burroughs Mountain moraines are only a few yards beyond moraines formed within the last 700 or 800 years, although those of Winthrop Glacier represent a glacier 300 feet thicker than at any subsequent time. The largest Burroughs Mountain moraines occur in the areas adjacent to Winthrop Glacier and between Winthrop and Carbon Glaciers, and smaller ones have been identified at a few other places in the park. The Wonderland Trail crosses a Burroughs Mountain moraine of Winthrop Glacier on the west slope of Burroughs Mountain (fig. 4, locality 20). 


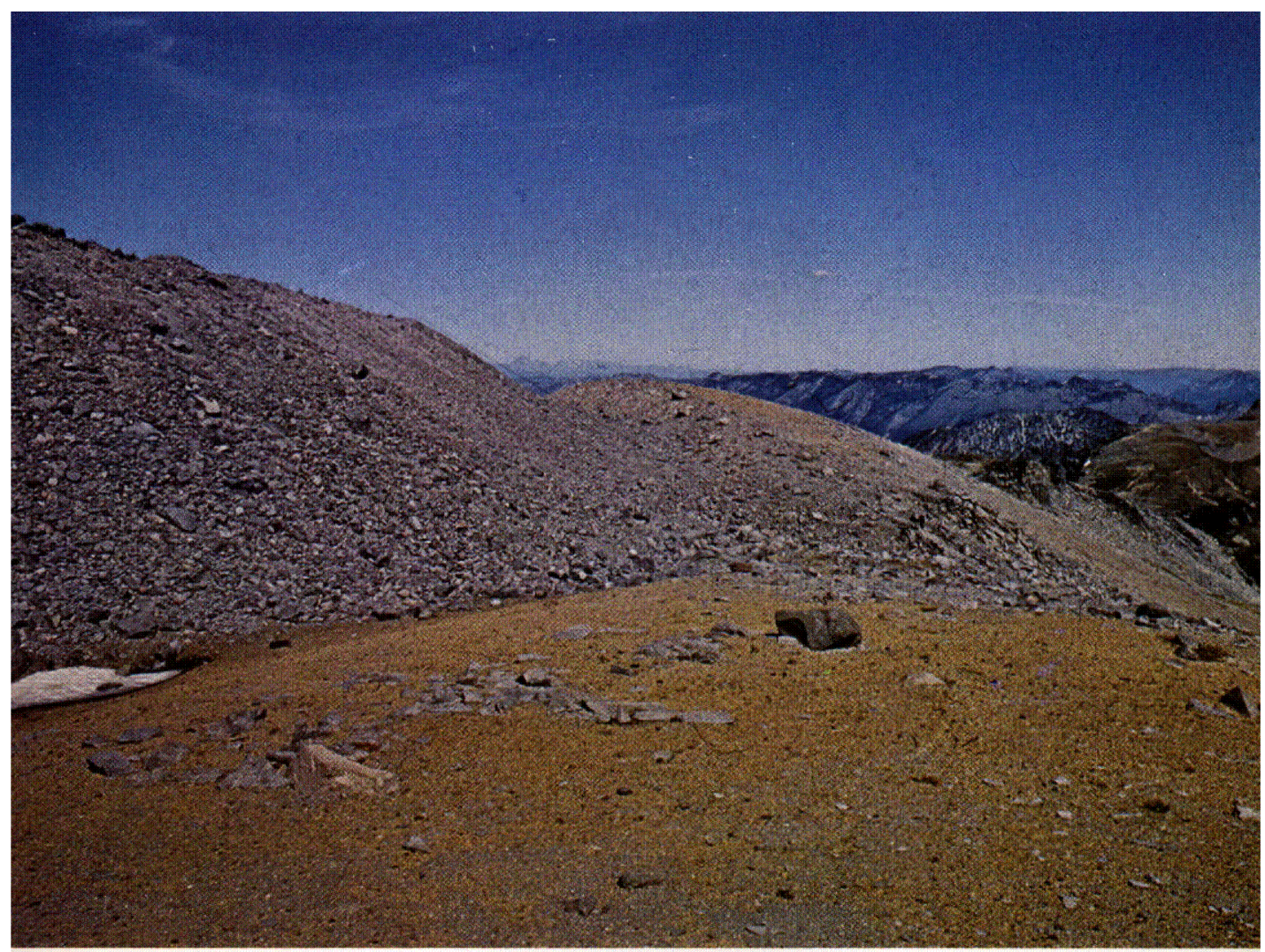

PUMICE LAYER $C$ forms a thin brown veneer on the drift in the foreground and on the Burroughs Mountain moraine in the center of the photograph. This pumice was erupted by Mount Rainier between 2,150 and 2,500 years ago. The Garda moraine of Fryingpan Glacier at the left has no pumice on it, and thus is younger. The large boulder in the middle foreground is about 6 feet long. This locality is at an altitude of 7,500 feet about a mile southwest of Panhandle Gap. (Fig. 14) 


\section{GARDA DRIFT}

Moraines formed since the eruption of pumice layer $\mathrm{C}$ are included in the Garda Drift (fig. 14) ; contemporaneous glacial melt-water deposits, however, are represented on the geologic map only as alluvium. The till consists of a gray unsorted mixture of pebbles, cobbles, and boulders in a silt and sand matrix and is unweathered. The presence or absence of pumice layer W divides Garda moraines into groups that are older or younger, respectively, than about 450 years. Trees growing on some Garda moraines are at least 750 years old. Moraines younger than layer $\mathrm{W}$ include stable, forested deposits decades or a few centuries old as well as subsiding masses of rock debris that still bury blocks of slowly melting ice. Younger Garda moraines are especially unstable on steep valley sides in areas from which glaciers have receded within the last half century. Boulders in the moraines become dislodged from time to time and roll and bound down to the valley floor at high speed. During periods of heavy rainfall or rapid snowmelt, saturated masses of drift sometimes move from the moraines onto the valley floors as mudflows.

Moraines of Garda Drift range in size from ridges only a few feet high and a few tens of feet wide to massive complex end moraines such as the one that was formed in the White River valley by Emmons Glacier between the 17th century and about 1910 (fig. 15; fig. 4, locality 21). Dates shown on individual moraines on the geologic map are based on the earliest growth ring of the oldest known living tree on the moraine; the moraine is older than the tree by an unknown number of years, perhaps as much as several decades. One of the most readily accessible Garda moraines in the park lies at the west end of the bridge across the Nisqually River (fig. 4, locality 22), 3.5 miles northeast of Longmire. This moraine is conspicuous because trees on it are much younger and smaller than those in the adjacent older forest. When this moraine was formed in 1840, Nisqually Glacier covered the site of the present highway and reached to a point about 750 feet downvalley from the bridge. 


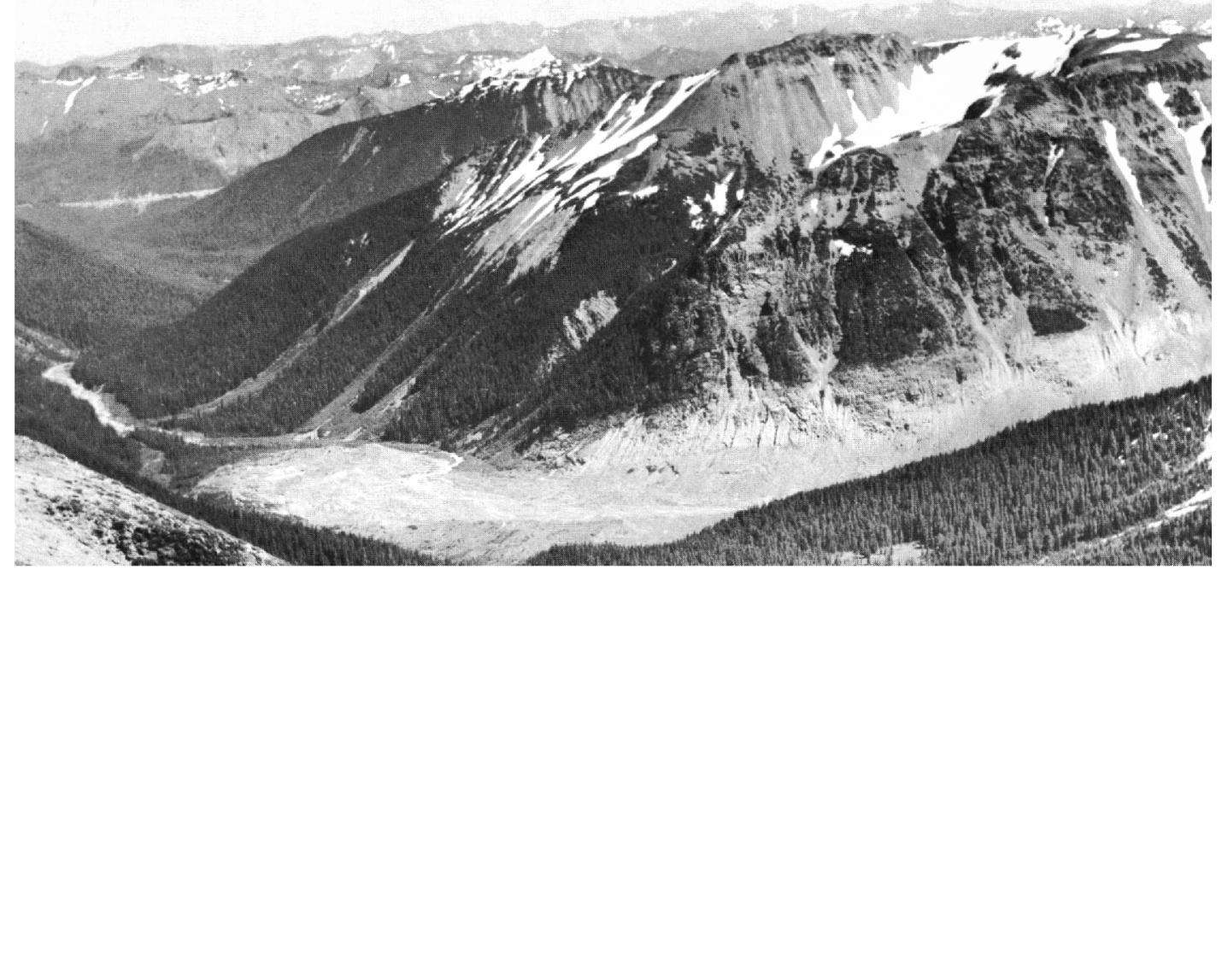

END MORAINE of Garda Drift formed by Emmons Glacier is a hummocky accumulation of bare rock debris in the center of the White River valley. When the ice front stood at the moraine, the upper surface of the glacier coincided with the conspicuous sloping trimline in the trees on the opposite valley wall. The exposure in the center foreground is that shown in figure 13. (Fig. 15) 


\section{BOMB-BEARING DEPOSIT IN SOUTH PUYALLUP RIVER VALLEY}

A deposit of unsorted and unstratified rock debris that contains many light-olive-gray breadcrust bombs is exposed along the highway in the South Puyallup River valley (fig. 4 , locality 23). Breadcrust bombs are formed when blobs of lava are thrown from a volcano; as the bomb cools, a solid skin forms, which then ruptures as gas pressure in the lava causes it to expand slightly. The bomb's exterior is a network of fissures and segments that resemble those on a loaf of hard-crusted bread; inside, most bombs are very porous because of the gas bubbles that formed in the lava (fig. 16). Many bombs have one flat side, which was formed when still-plastic blobs of hot lava struck the ground after flying through the air. Bombs in the South Puyallup River valley are 6 inches to 4 feet in diameter.

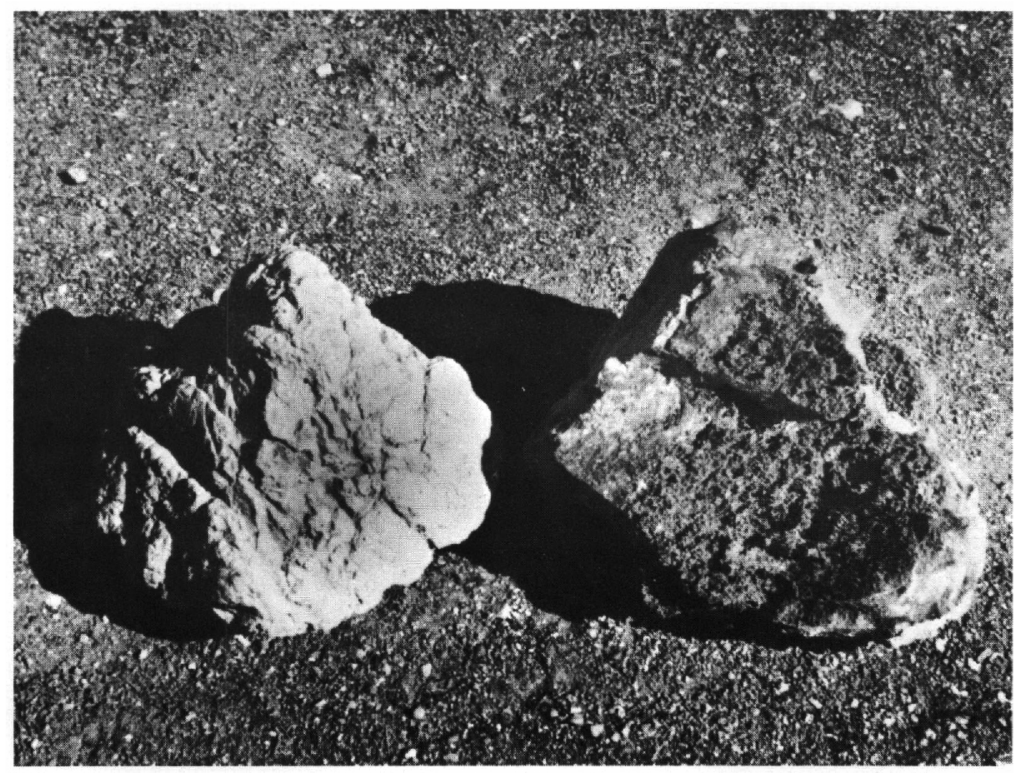

BREADCRUST BOMB on the left shows a typical cracked and segmented surface formed during cooling; the other bomb is broken open to show the black bubbly interior. The bombs are about 10 inches in diameter. (Fig. 16) 
The bombs are contained in a deposit of loose purplishgray sand. Although the bombs are the most conspicuous part of the deposit, fragments of dense glassy dark-gray andesite as much as several inches in diameter are also abundant. The deposit is at least 200 feet thick in places, and it overlies very coarse mudflows and alluvium in which no bombs were seen. On top of the deposit are two thin clayey mudflows which probably were formed about 1,000 and 600 years ago, respectively. A carbonized log 4 feet long that was found just above the base of the bomb-bearing deposit had a radiocarbon age of about 2,500 years. Streams have eroded the bomb-bearing deposit to form ridges that greatly resemble lateral moraines near the West Side Road.

The deposit originated when hot rock rubble, ash, and bombs avalanched from the top of the volcano during an eruption. Even though the rock debris flowed down the South Puyallup River valley in a fluid manner, the magnetic properties of rock fragments indicate temperatures of hundreds of degrees above the boiling point of water when movement stopped. Thus, the rock debris must have flowed in a dry condition, and it probably was "lubricated" by steam, hot air, and other gases.

\section{MUDFLOWS}

As many as five mudflows, each of which is from a few feet to several tens of feet thick, lie on low terraces, valley sides, and some ridgetops in and adjacent to the valleys of Tahoma Creek and the North and South Puyallup Rivers (fig. 17). All have been formed within the last 4,000 years, and one is only about 440 years old. The mudflows are unsorted mixtures of boulders of many sizes in a yellowishorange matrix of sand, silt, and clay. One, exposed in roadcuts at Round Pass (fig. 4, locality 24), can be traced along a trail to Lake George to a height of about 350 feet vertically higher than the pass, which indicates that the Tahoma Creek valley temporarily must have had at least 1,000 feet of mud flowing in it. Remnants of the deposit on the sides of the South Puyallup River valley indicate a comparable thickness or depth there. At Indian Henry's Hunting Ground, on the divide between the Tahoma Creek and Kautz Creek valleys, the southwest margin of the mudflow forms an abrupt front about 17 feet high where it is crossed by 
the Wonderland Trail (fig. 4, locality 25). The boundary there between the mudflow and the adjacent surface is conspicuous because pumice layer $\mathrm{Y}$ abruptly disappears as one passes from the older surface onto the mudflow.

The approximate maximum height of the deepest mudflows in the valleys west of the volcano, shown by a heavy dashed line on the geologic map, is reconstructed from the highest known remnants of the deposits; this line probably represents the height attained by a single mudflow that occurred about 2,800 years ago. Another mudflow temporarily reached almost as high on the valley sides about 600 years ago. It had enough volume to move 25 miles downvalley and to extend an additional 15 miles into the Puget Sound lowland. All the mudflows originated in avalanches of clay and altered rock from the west side of the volcano at Sunset Amphitheater (frontispiece).

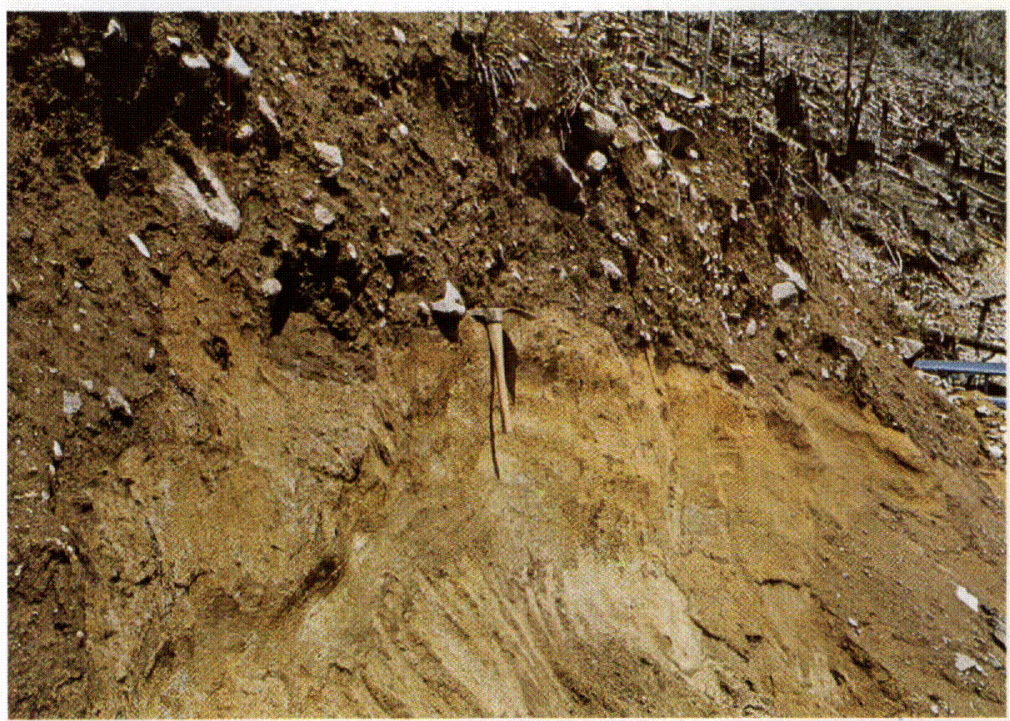

MUDFLOW from Mount Rainier is the dark-brown deposit above the head of the pick; it lies on top of yellow pumice (layer Y) from Mount St. Helens which is between 3,250 and 4,000 years old. This locality is on the north side of the North Puyallup River valley a mile west of the park boundary. Its height of about 240 feet above the valley floor indicates that the mudflow was temporarily at least 240 feet deep here. The pumice is unusually thick. (Fig. 17) 


\section{TALUSES}

Taluses are loose accumulations of coarse rock fragments that lie beneath cliffs (fig. 10). Their surfaces slope at angles ranging from about $30^{\circ}$ to $35^{\circ}$. Rock fragments in a talus are generally fresh and angular and range in size from pieces a few inches across to blocks that are several tens of feet in maximum diameter. Some taluses have bulbous toes that suggest movement by flowage, perhaps caused by ice within the rock debris. Taluses that are wholly forested are not shown on the geologic map.

\section{BLOCK-FIELD DEPOSITS}

Block-field deposits consist of angular rock fragments that lie on both sloping and horizontal surfaces. The rock fragments are pried from the underlying solid rock formations by the repeated freezing and expansion of moisture in cracks. Some block fields resemble taluses in that they have slopes of as much as $35^{\circ}$, but they differ in that they are not littered with very large blocks and do not have a cliff at their head. Downslope-trending bands of vegetated and unvegetated rock debris a few feet to a few tens of feet wide give some sloping block fields a distinctly striped appearance. Other fields end downslope in elongate lobes of rock debris a few feet to several tens of feet wide and 1-4 feet thick. The shape of these lobes suggests that they originated from flowage of the rock debris, perhaps caused by saturation from rain or melting snow. Block fields are not common where rock debris produced by frost action consists mostly of fragments smaller than 3 inches in diameter. Some block fields probably date from the last major glaciation, and others may be of more recent age.

Especially well developed and easily accessible block fields are crossed by the trail to the Mount Fremont fire lookout (fig. 4, locality 26). 


\section{LANDSLIDE DEPOSITS}

Landslides consist of chaotic mixtures of loose rock debris, or several very large blocks of rock, that have broken away from the bedrock and have moved downslope. They include those which seem to be inactive and those in which there was evidence of movement during the period of field study (1960-67). An example of an inactive slide is one that originated in west-dipping bedrock just north of Ohanapecosh campground (fig. 4, locality 27). Cuts in this landslide along State Highway 143 expose a jumbled mixture more than 100 feet thick of rock fragments of many sizes in which some layers or zones have a plastic purplish-gray clay matrix. The surface of the slide deposit is hummocky, includes closed depressions, and is strewn with angular blocks as much as $\mathbf{1 5}$ feet across. Another inactive slide is crossed by the Mather Memorial Parkway (U.S. Highway 410) half a mile north of Cayuse Pass (fig. 4, locality 28). The slide originated in west-sloping bedrock and descended into the valley of Klickitat Creek, where it now impounds Ghost Lake. Highway cuts through the slide deposit show a loose mixture of rock fragments of many sizes, some as large as 20 feet across.

An active landslide is slowly moving down the west slope of Backbone Ridge (fig. 4, locality 29). It consists of a jumbled mass of sandstone and claystone, probably only about 25 feet thick. From 1962 to 1966 the slide moved at an average rate of about 6 inches per year.

An active slide on the west side of the Nisqually River valley west of Paradise Park involves lava flows from the volcano as well as the underlying bedrock. The slide block seems to be dropping eastward toward the center of the valley and rotating, so that the north side of the block is moving more than the south side. The slide is broken into several smaller blocks by cracks that parallel the 1,000-footlong main crack at the slide's head. Photographs taken in 1912 show the fresh scarp at the head of the slide, so it evidently began to move at some earlier time. The slide can be seen from various viewpoints along the trail from the Paradise visitor center to Panorama Point. 


\section{TRAVERTINE}

Travertine is a calcium carbonate mineral that has been deposited by the water of warm or hot springs. Deposits of yellowish-orange to white travertine of unknown thickness that underlie parts of a meadow at Longmire and a small area near Ohanapecosh campground have been formed by warm spring water that still issues from the ground at both localities. Pumice layer $\mathrm{W}$ is interbedded with the travertine near Ohanapecosh campground.

\section{ALLUVIAL CONES}

Alluvial cones are steeply sloping, poorly sorted stream deposits of loose rock debris which lie beneath cliffs and are wedge shaped in ground plan (fig. 18). Their surfaces are

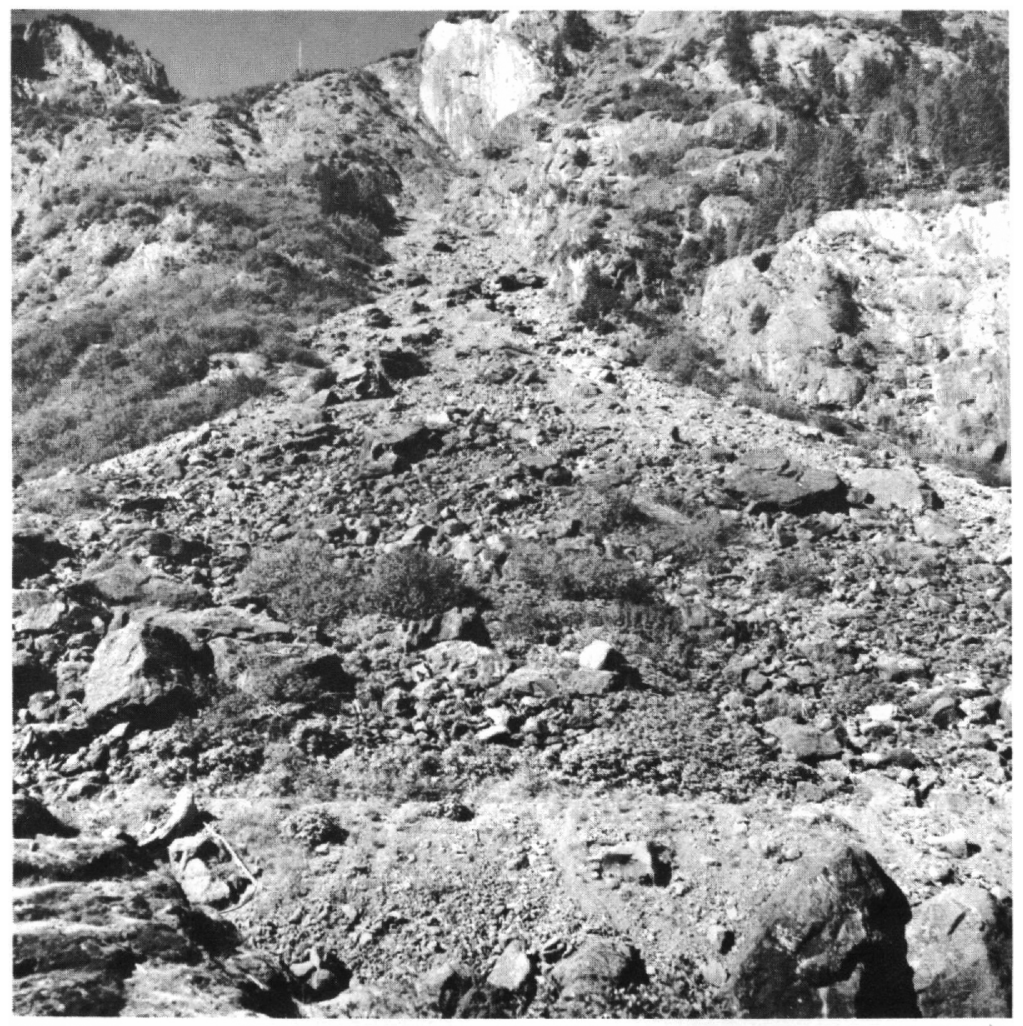

ALLUVIAL CONE at the east base of Mount Wow. The largest blocks in the deposit are about 20 feet in diameter. (Fig. 18) 
scarred by one or more gullies, the sides of which are paralleled by low bouldery ridges 5-25 feet wide and 3-10 feet high. Some cones seem to consist chiefly of rock fragments larger than 6 inches in diameter, but others are rich in debris of sand and pebble sizes. Very large blocks lie on the surface of some cones. Alluvial cones are distinguished from taluses by less steep slopes, by a markedly decreasing slope toward the toe, and by stream-gullied surfaces. Most cones head at the mouths of steep rock-walled gullies and have been formed by small streams and mudflows that descend the gullies during rainstorms. From Ricksecker Point, a typical alluvial cone can be seen on the opposite side of the Paradise River valley (fig. 4, locality 30 ), and the West Side Road crosses one at the base of Mount Wow (fig. 4, locality $31)$.

\section{ALLUVIUM}

Alluvium includes both unvegetated sand and pebble-toboulder gravel deposited by modern streams and rivers and the same type material underlying forested terraces or benches as much as 15 feet higher than the stream channels. Some low terraces contain poorly sorted bouldery deposits that may be mudflows or alluvium transported by floods. Near the ends of present glaciers, alluvium locally includes lenticular mudflows a few feet thick that came from moraines or from rock debris on the glaciers; boulders larger than 5 feet in diameter in the alluvium probably were carried by these mudflows. Nearly all the alluvium shown on the geologic map has been formed within the last 500 years.

\section{AVALANCHE DEPOSITS FROM LITTLE TAHOMA PEAK}

Seven or more rockfalls from the steep north face of Little Tahoma Peak in December 1963 resulted in a series of large avalanches that rushed as far as 4.3 miles downvalley. Although these avalanches were a form of landslide, they differed from most other landslides of the park in their speed. An extremely high velocity, probably exceeding 100 miles per hour, is indicated by the height to which some avalanches rose onto the sides of obstacles in their paths. 
Such a velocity is also suggested by the way some avalanches caromed from one side of the valley to the other during movement, by their distance of movement, and by the presence of rock fragments embedded in the trunks of trees along the south margin of the avalanches a quarter of a mile upvalley from White River campground.

The avalanche deposits are jumbled mixtures of angular rock debris of many sizes in a loose reddish-gray matrix of sand (fig. 19). Scattered blocks of andesite breccia in the deposits are as large as 60 by 130 by 160 feet. The surface of the avalanche deposits is hummocky in most areas, but in some places there are ridges and furrows in the debris. Some

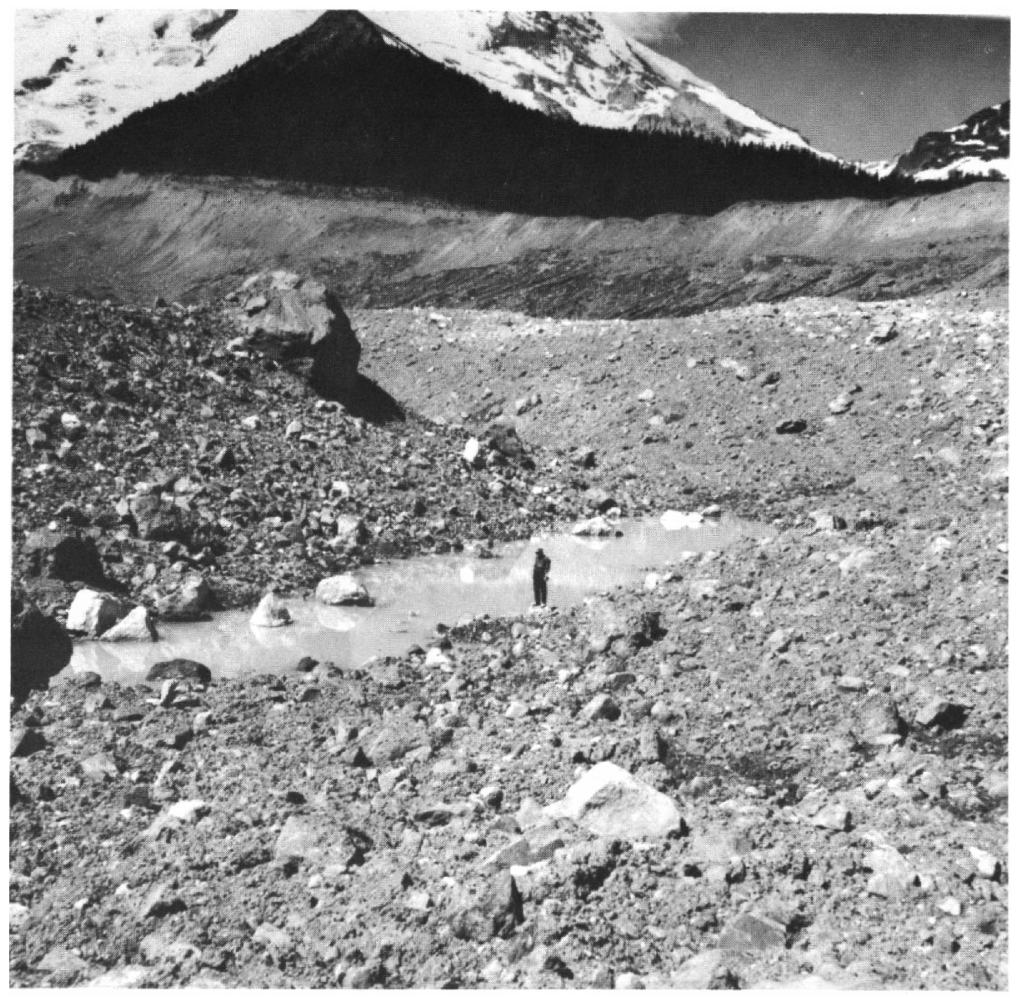

AVALANCHE DEPOSIT of rock debris in the foreground originated in rockfalls from Little Tahoma Peak. The deposit buried the former floor of the White River valley to depths as great as 100 feet. The boulder on the ridge at the left has dimensions of about 24 by 30 by 46 feet. (Fig. 19) 
ridges and furrows parallel the trend of the valley, and others are transverse to it. The deposits have a maximum thickness of about 100 feet, and they originally covered an area of about 2 square miles, including the part on the surface of Emmons Glacier. The total volume is estimated to be at least 14 million cubic yards.

The long distance some avalanches moved is attributed to the development of cushions of compressed air beneath the avalanches as they hurtled off the steep front of Emmons Glacier. These air cushions buoyed up the swiftly moving avalanches for long distances and prevented them from striking the ground.

\section{Perspective}

The surficial deposits of Mount Rainier National Park record a complex series of events that have occurred within the recent geological past. Glaciers formed the oldest deposits very early in the history of Mount Rainier, perhaps even before the volcano as we know it today began to develop. Huge glaciers again blanketed almost the entire park twice during the last $40,000-50,000$ years. The last of these major glaciations ended only about 10,000 years ago, but within just the last few thousand years the glaciers of the park have experienced renewed growth at least twice.

Mount Rainier has erupted repeatedly since the end of the last major glaciation, but most of this activity has been on a feeble scale in comparison with the cataclysmic eruptions that built the main cone. The production of new lava and pumice, some as recently as the mid-1800's, has not kept pace with the piecemeal destruction of the volcano by glacial erosion and repeated landslides. Some of these slides have had wide-reaching effects, for at least two mudflows generated by them were large enough to reach far down valleys and to bury parts of the adjacent Puget Sound lowland.

Although all the surficial deposits were created by geologic events of the past, when viewed in the immense perspective of geologic time-measured in hundreds of millions of years-these events occurred only yesterday or early this morning; in all probability they will recur tomorrow. 


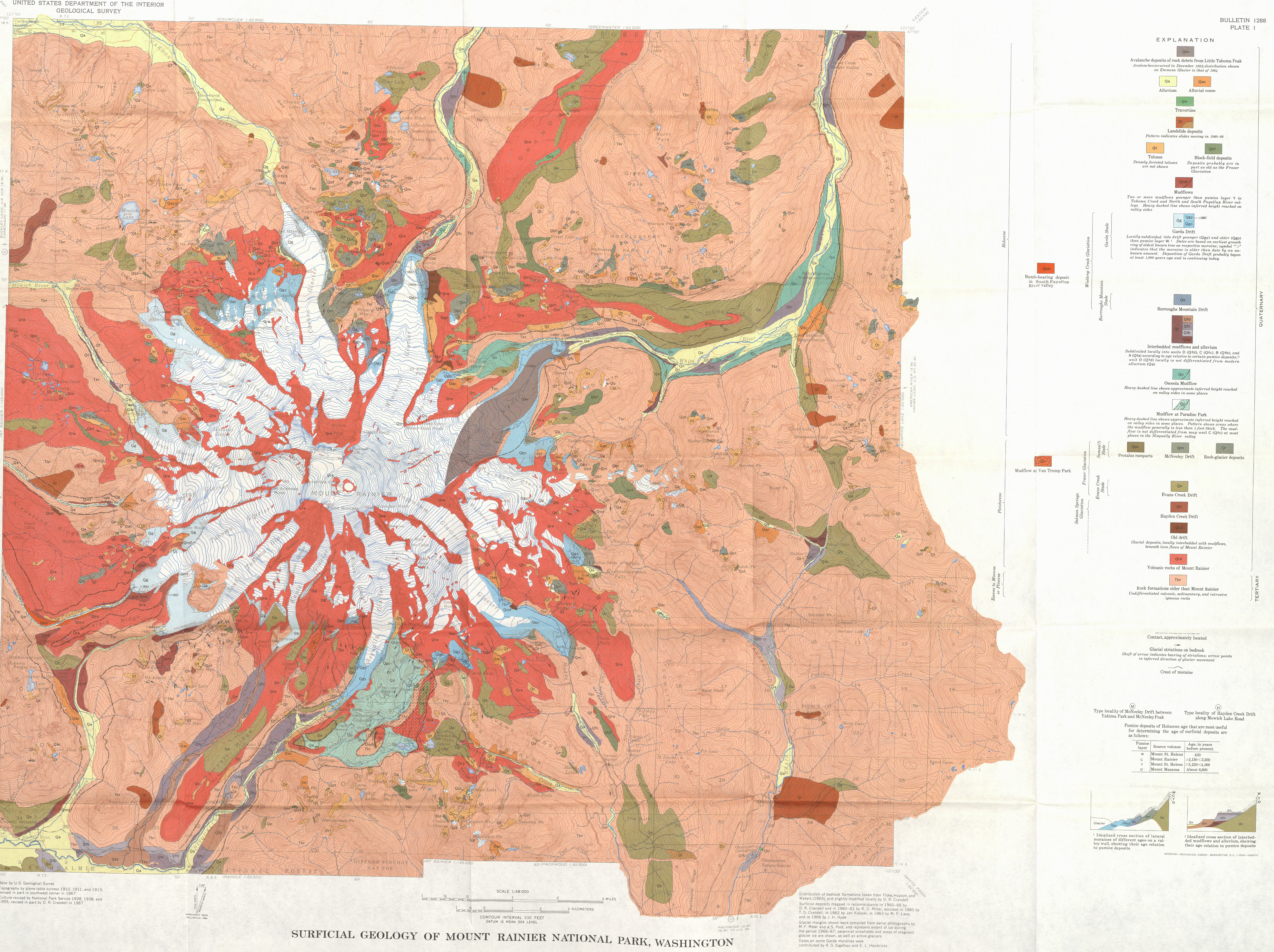


